\title{
Polyphase dolomitisation of the Wuchiapingian Zechstein Limestone (Ca1) isolated reefs (Wolsztyn Palaeo-Ridge, Fore-Sudetic Monocline, SW Poland)
}

\author{
Marek JASIONOWSKI ${ }^{1, *}$, Tadeusz Marek PERYT ${ }^{1}$ and Tomasz DURAKIEWICZ ${ }^{2,3}$ \\ 1 Polish Geological Institute - National Research Institute, Rakowiecka 4, 00-975 Warszawa, Poland \\ 2 Maria Curie-Skłodowska University, Mass Spectrometry Laboratory, Institute of Physics, 20-031 Lublin, Poland \\ 3 Los Alamos National Laboratory, Los Alamos, New Mexico 87545, USA
}

\begin{abstract}
Jasionowski, M., Peryt, T.M., Durakiewicz, T., 2014. Polyphase dolomitisation of the Wuchiapingian Zechstein Limestone (Ca1) isolated reefs (Wolsztyn Palaeo-Ridge, Fore-Sudetic Monocline, SW Poland). Geological Quarterly, 58 (3): 503-520, doi: 10.7306/gq.1194

Dolomitisation was the main diagenetic process in the Upper Permian Zechstein Limestone of the Wolsztyn High - dolomite cementation ("over-dolomitisation") also occurred. The rocks studied usually have a mixed mineralogy and represent a continuous spectrum from pure limestone to pure dolomite. This is due to varying degrees of dolomitisation, dolomite cementation and dedolomitisation. There are two main types of dolomite: replacement dolomite (mostly planar unimodal dolosparite mosaics that are mainly fabric-destructive) and cement dolomite (planar isopachous rims and pore-filling non-planar saddle-dolomite crystals). The timing of dolomitisation and dolomite cementation is difficult to ascertain, but comparing petrographical and geochemical data indicates that the reef carbonates were dolomitised shortly after deposition in a near-surface sabkha/seepage-reflux and then in burial systems. It seems that many of the dolomites gain their present isotopic composition when buried in relatively high-temperature conditions, as shown by low oxygen isotopic ratios $\left(\delta^{18} \mathrm{O}\right.$ as low as $\left.-9 \% \mathrm{PDB}\right)$ and the presence of saddle dolomite. No isotopic support for a water-mixing mechanism is documented.
\end{abstract}

Key words: Zechstein Limestone, reefs, diagenesis, dolomitisation, carbon and oxygen isotopes.

\section{INTRODUCTION}

Although the origin of dolomite remains subject to considerable controversy, geochemical data and numerical models suggest that most regionally extensive dolomites form(ed) at temperatures around $50-80^{\circ}$, commensurate with depths of $500 \mathrm{~m}$ to a maximum of $2000 \mathrm{~m}$ (e.g., Machel, 2004). However, even the smallest dolomite crystal may be a composite crystal resulting from multiple, time-separated phases of dolomitisation. It is difficult to assign particular petrographic features and/or geochemical signatures to specific phases of dolomitisation (Jones, 2005) as primary dolomitisation of a limestone by basinal fluids generates similar characteristics to those of a replacive burial dolomite (Machel and Burton, 1991; cf. Warren, 2000). In addition, the formation of numerous dolomite bodies was driven not by one, but by several mechanisms of dolomitisation (e.g., Nader et al., 2004; Chen et al., 2004; Garcia-Fresca et al., 2012).

The Upper Permian Zechstein dolomites are products of both early and late diagenesis (e.g., Füchtbauer, 1980; Clark, 1980; Peryt, 1984, 1987; Tucker and Hollingworth, 1986; Becker, 2002) and the pattern of the occurrence of dolomite is complex (e.g., Lorenc, 1975; Kijewski, 1981; Peryt, 1984;

\section{* Corresponding author: marek.jasionowski@pgi.gov.pl}

Received: August 1, 2014; accepted: September 8, 2014; first published online: September 30, 2014
Michalik, 2001). As far as early diagenetic dolomites are concerned, those from the Zechstein Limestone (that preceded the evaporite deposition - Fig. 1) of marginal carbonate platform facies in SW Poland show a broad range of nearly $7 \%$ of $\delta^{18} \mathrm{O}$ values (average $-1 \%$ ) and a relatively narrow range $(\approx 3.5 \%$ ) of $\delta^{13} \mathrm{C}$ values (average +4.6\%) (Magaritz and Peryt, 1994). These dolomites were thought to have formed via meteoricseawater mixing (Magaritz and Peryt, 1994) and such an interpretation for dolomites from the Bonikowo 1 section (located on the Wolsztyn High in SW Poland) showing $\delta^{18} \mathrm{O}$ values -0.67 to $-7.24 \%$ was accepted by Sylwestrzak (2000). However, the study of Melim et al. (2004) of mixing-zone diagenesis combined with a critical examination of literature data advocates rejection of the mixing-zone dolomitisation model. Dolomites of the Zechstein Main Dolomite (sandwiched between evaporites - Fig. 1) in SW Poland show relatively large $\delta^{18} O$ values (average $2-3 \%$ ), with a broader range of nearly $5 \%$. $\delta^{13} \mathrm{C}$ values show a relatively limited range $(\approx 4 \%)$ but a very large average value $(7 \%)$, and are inferred to have been derived from very early (near-surface) reflux of dense, hypersaline, Mg-rich brines (Peryt and Scholle, 1996).

In the basinal facies of the Zechstein Limestone in SW Poland, reefs were encountered (Fig. 2), and they are surrounded laterally and overlain by evaporites (Dyjaczynski et al., 2001; Dyjaczyński and Peryt, 2014). The purpose of this paper is to define the mechanisms and timing of dolomitisation in those reefs, as concluded from carbon and oxygen isotopic investigations combined with a petrographic study. 


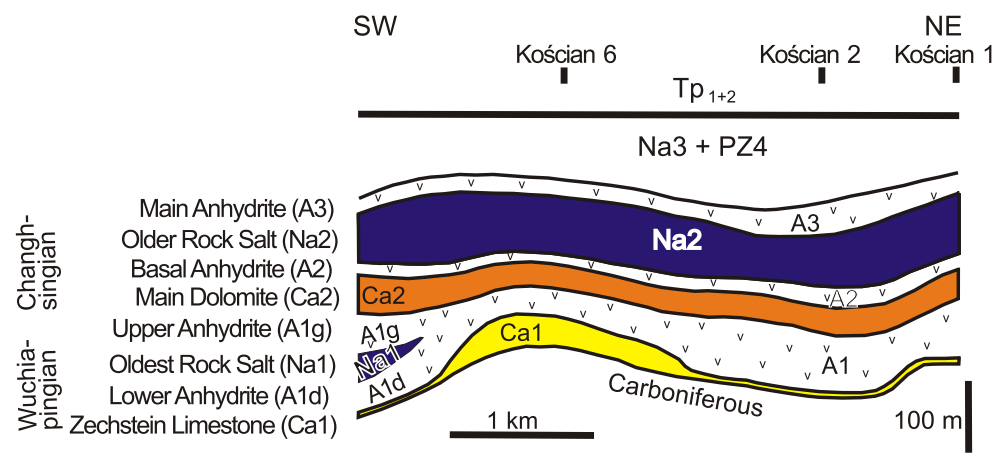

Fig. 1. Stratigraphy of basal and middle parts of the Zechstein (Peryt et al., 2010a with references therein) shown on an example of an interpreted seismic section controlled by three boreholes (location of the section is shown in Fig. 2C)

$\mathrm{Na} 3$ - Younger Halite, $\mathrm{Tp}_{1+2}$ - Lower and Middle Buntsandstein playa lake, aeolian and wadi deposits up to $1000 \mathrm{~m}$ thick accumulated during Middle and the earliest Late Permian times. Those siliciclastic rocks are absent from the Wolsztyn Ridge or are replaced by coeval volcanic rocks (Kiersnowski et al., 1995, 2010).

Deposition in the Polish Zechstein Basin commenced with flooding of the continental Rotliegend basin (e.g., Peryt et al., 2012a with references therein). The first basin-wide lithological unit is the Kupferschiefer, absent from most marginal parts of the Zechstein Basin as well as from more elevated parts of the Wolsztyn Palaeo-Ridge. It is followed by dolomites and limestones of the first cycle carbonate, the Zechstein Limestone. In the area studied, reef complexes were formed on more eminent elevations related to the central part of the Wolsztyn PalaeoRidge (Dyjaczynski et al., 2001; Kiersnowski et al., 2010; Peryt et al., 2012b). The thickness of reef complexes reaches $90.5 \mathrm{~m}$. Biofacies sequence and the dominant fauna of those reefs (Raczyński, 2000; Peryt et al., 2012b) show remarkable similarity to the isolated reefs described by Füchtbauer (1980) from NW Germany. Coeval basinal sections of the Zechstein Limestone are very thin in the area studied, often $<1 \mathrm{~m}$ thick, and consist of limestone and/or dolomite (Dyjaczynski et al., 2001; Kotarba et al., 2006; Peryt et al., 2014; Dyjaczyński and Peryt, 2014).

In the sections of reef complexes of the Wolsztyn High zone, five units can generally be distinguished: (i) breccia (characterized by D. Peryt et al., 2012); (ii) bioclastic grainstones with extraclasts, (iii) bioclastic grainstones and packstones with abundant anhydrite; (iv) bioclastic wackestones-grainstones with intraclastic breccia and carbonate crusts; (v) stromatolitic-
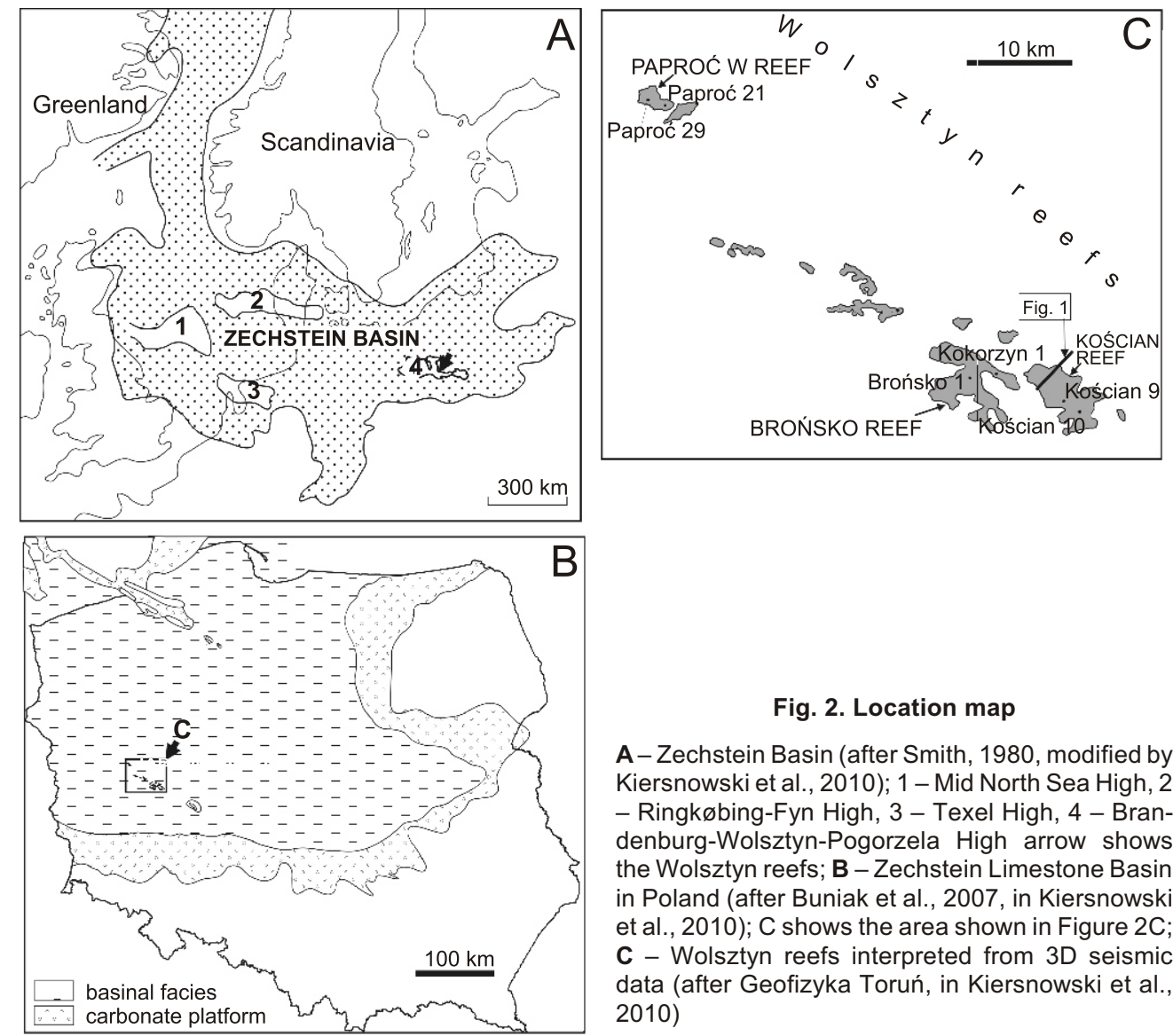

Fig. 2. Location map

A-Zechstein Basin (after Smith, 1980, modified by Kiersnowski et al., 2010); 1 - Mid North Sea High, 2 - Ringkøbing-Fyn High, 3 - Texel High, 4 - Brandenburg-Wolsztyn-Pogorzela High arrow shows the Wolsztyn reefs; $\mathbf{B}$ - Zechstein Limestone Basin in Poland (after Buniak et al., 2007, in Kiersnowski et al., 2010); C shows the area shown in Figure 2C; C - Wolsztyn reefs interpreted from 3D seismic data (after Geofizyka Toruń, in Kiersnowski et al., 2010) 
pisolithic carbonates (Dyjaczynski et al., 2001; Kiersnowski et al., 2010; Peryt et al., 2012b). In places where units (iii) and (iv) are absent and deposits of unit (v) lie directly on those of unit (ii), units (iii) and (iv) were either not deposited or were eroded prior to unit (v) deposition (Dyjaczynski et al., 2001). Where present, units (iii) and (iv) constitute the major part of the Zechstein Limestone section, and unit (v) is mostly several metres thick.

Units (i)-(iv) in general reflect deposition in subaqueous environments, whereas unit (v) originated in very shallow water and a temporarily subaerial environment. Unit (i) is interpreted as a transgressive systems tract (TST; D. Peryt et al., 2012), units (ii)-(iv) as a highstand systems tract (HST), and unit (v) as a lowstand systems tract (LST) (Dyjaczynski et al., 2001). The overlying Lower Anhydrite shows a breccia-like appearance, nodular anhydrite with clasts of red mudstone occurring, topped by selenitic anhydrite with upward-fining crystals (Peryt et al., 2010b; Hryniv and Peryt, 2010). The (recrystallised) anhydrite with clear pseudomorphs after selenite crystals form the greater part of the anhydrite platform sections that are related to the elevated areas within the basin (among them, reef zones), and in the depressed area coeval halite deposits have formed (Dyjaczyński and Peryt, 2014). The deposition of the PZ1 evaporites levelled off the earlier existing relief, making the upper surface of the PZ1 deposits roughly planar (Dyjaczynski et al., 2001: fig. 2; Dyjaczyński and Peryt, 2014).
The subsequent depositional and burial history of the Zechstein Limestone deposits of the Wolsztyn Palaeo-Ridge was the same as that of the entire Fore-Sudetic Monocline that constituted a part of the Polish Basin (e.g., Kotarba et al., 2006). During Late Permian and Mesozoic times, continual subsidence took place with periods of accelerated subsidence, until the Turonian to Paleocene tectonic inversion of the Polish Basin (see Resak et al., 2007; Krzywiec et al., 2009; and references therein). At present, the base of the Zechstein Limestone lies at a depth of $2.0-2.5 \mathrm{~km}$, and at the end of Jurassic it was located at a depth of ca. $3.5 \mathrm{~km}$ (Karnkowski, 1999: fig. 29). The present temperature at that depth is ca. $80^{\circ} \mathrm{C}$ (Karnkowski, 1999: fig. 42).

\section{MATERIAL AND METHODS}

In this paper we report the results of study of the Zechstein Limestone carbonates in six selected boreholes; two of them are located in the Kościan Reef (Kościan 9 and 10), two in the Paproć Reef (Paproć 21 and 29), and two in the Brońsko Reef (Brońsko 1 and Kokorzyn 1; Figs. 2 and 3). Of those six boreholes, the Zechstein Limestone of the Brońsko 1 borehole was characterized by Dyjaczynski et al. (2001), and the Kokorzyn 1 borehole by Sylwestrzak (2000). Jasionowski et al. (2000) and Jasionowski (2010) presented a preliminary interpretation of stable isotope study of the Zechstein Limestone in other boreholes.
Kokorzyn 1

$\begin{array}{lllllllllll}-10 & -8 & -6 & -4 & -2 & 0 & 2 & 4 & 6 & 8 & 10\end{array}$

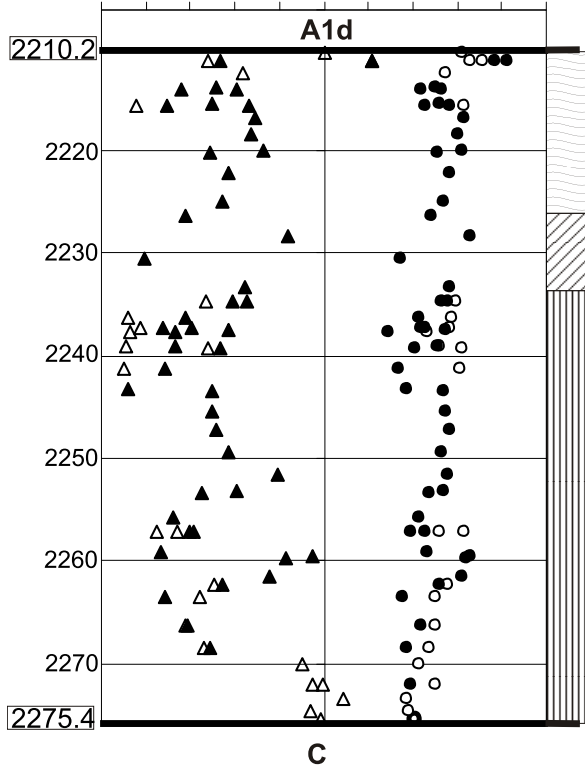

Paproć 21

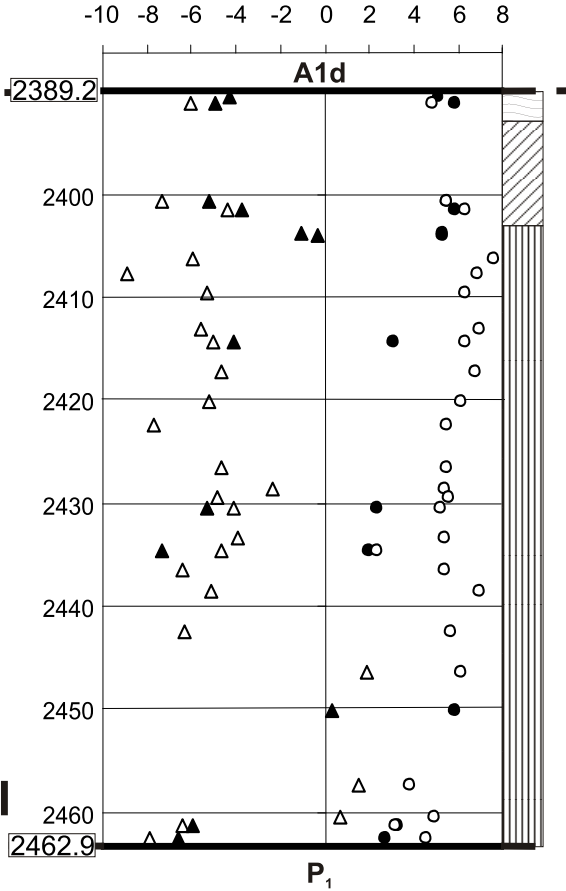

Kościan 10

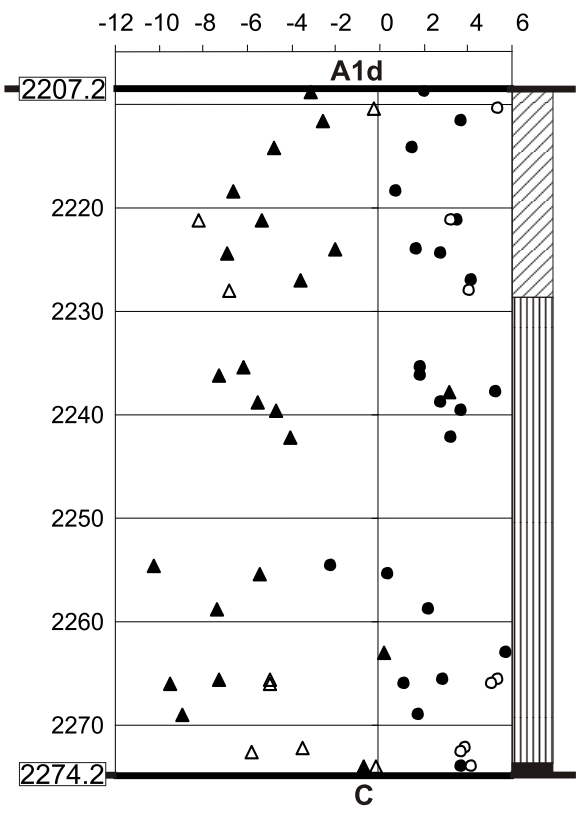

Unit V LST (Lowstand Systems Tract) $Z \subset$ Unit IV HST (Highstand System Track)
IIIIII Unit III HST (Highstand Systems Tract) Unit II HST (Highstand System Track)
Unit I TST (Transgressive Systems Tract) $\square$ Unit II HST (Highstand System Track)

Fig. 3. Lithological and $\delta^{13} \mathrm{C}$ and $\delta^{18} \mathrm{O}$ logs of selected Zechstein Limestone sections

Triangles $-\delta^{18} \mathrm{O}$, circles $-\delta^{13} \mathrm{C}$, solid symbols - calcite, open symbols - dolomite; units of the Zechstein Limestone after Dyjaczynski et al. (2001) 
Thin sections (332 in total, including 49 for CL study) were stained with Alizarin Red $\mathrm{S}$ and potassium ferricyanide to assist in the identification of dolomite and to assess the Fe content of the carbonates. They were studied under a polarizing microscope. The petrographic analysis was enhanced by cathodoluminescence observations. In addition, fresh rock samples and thin sections were examined using a scanning electron microscope (SEM), and backscattering and microprobe studies were carried out. To establish the mineralogical composition and the stoichiometry of dolomite, analyses of 54 samples were made using the X-ray diffraction method in the Central Chemical Laboratory of the Polish Geological Institute - National Research Institute in Warszawa. The Philips X-ray Diffractometer System PW1840 with Cu-tube and solid state detector provided with an automatic computerized powder identification system $A P D 1877$ was used.

205 samples were studied for oxygen and carbon isotopes at the Institute of Physics, Maria Curie-Skłodowska University, Lublin, Poland. For isotopic analyses of limestone, $\mathrm{CO}_{2}$ gas was extracted from the samples by the reaction of calcite with $\mathrm{H}_{3} \mathrm{PO}_{4}$ (McCrea, 1950) at $25^{\circ} \mathrm{C}$ in a vacuum line, following the standard. The gas was purified of $\mathrm{H}_{2} \mathrm{O}$ on a $\mathrm{P}_{2} \mathrm{O}_{5}$ trap and collected on a cold finger. Isotopic compositions were analysed using a modified Russian Ml1305 triple-collector mass spectrometer (Durakiewicz, 1996) equipped with a gas ion source. Isobaric correction was applied. After subsequent normalisation to measured certified reference materials, the isotopic composition was expressed in per mille (\%o) relative to the VPDB international standard and separately to PDB. Analytical precision of both $\delta^{13} \mathrm{C}$ and $\delta^{18} \mathrm{O}$ in a sample was $\pm 0.08 \%$.

The temperatures of calcite and dolomite precipitation were interpreted using the temperature-dependence of the ${ }^{18} \mathrm{O}-{ }^{16} \mathrm{O}$ fractionation factors between calcite and fluid, and dolomite and fluid (oxygen isotope thermometry), according to equations given respectively by Vasconcelos et al. (2005) and Friedman and O'Neil (1977) for low- and high-temperature dolomites.

\section{RESULTS}

\section{MINERALOGY}

Petrographical and X-ray studies indicated that the Zechstein Limestone rocks usually are of a mixed composition and represent a continuous spectrum from pure limestone to pure dolomite (Fig. 4 and Appendix $1^{*}$ ). This is due to varying degrees of dolomitisation, dolomite cementation and dedolomitisation. The rocks contain varied amounts of anhydrite (even to more than a half of rock volume - Fig. 4 and Appendix 1) and other subordinate and accessory authigenic minerals: fluorite, ankerite, quartz, celestine, clay minerals, galena, sphalerite, pyrite, apatite, in addition to siliciclastic and volcanogenic clasts recorded especially in the lower unit of the Zechstein Limestone (cf. D. Peryt et al., 2012).

X-ray study and then the calculation of molar concentration of $\mathrm{CaCO}_{3}$ in dolomite based on the position of peak $d_{104}$ (Lumsden, 1979) showed that the dolomites are mostly nonstoichiometric and are characterized by quite varied $\mathrm{CaCO}_{3}$ content, although most of the values are within the range $47-52 \%$, with the dominant range $49-50 \%$ (Fig. 5 and Appendix 1). No clear relation between the calculated dolomite

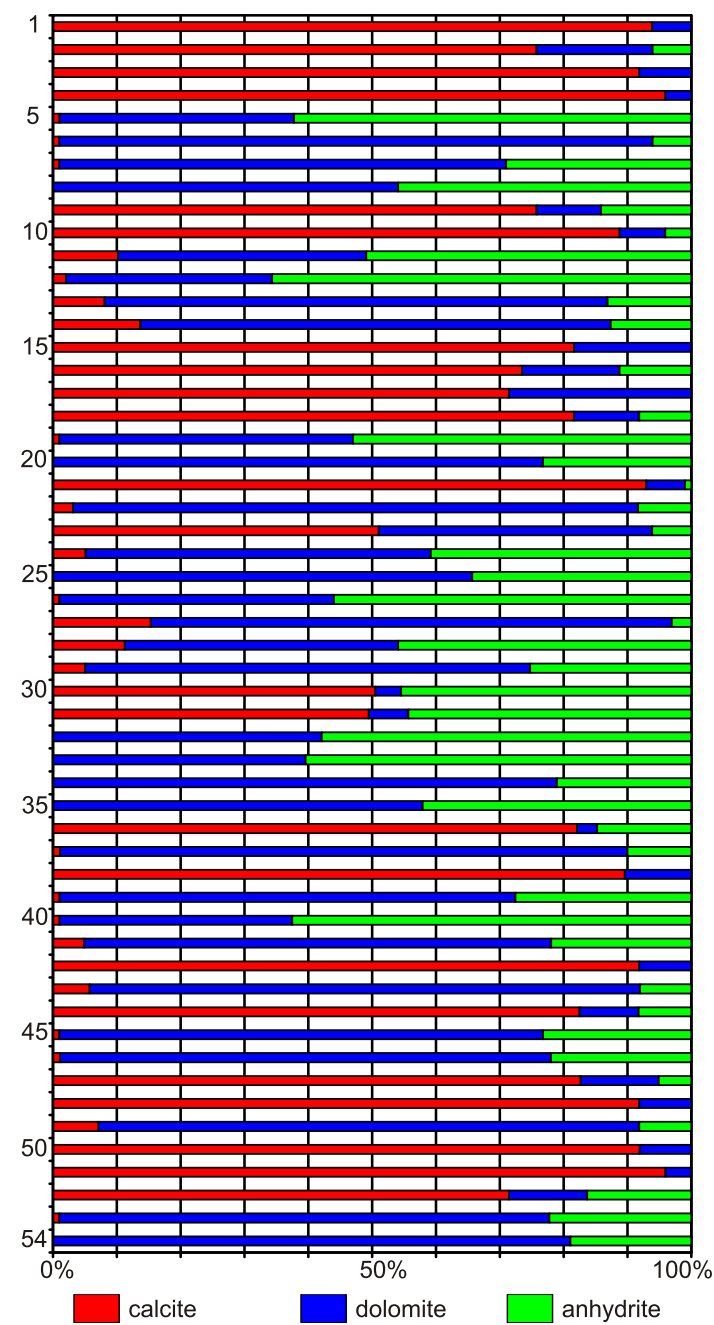

Fig. 4. Calcite, dolomite and anhydrite content in the samples studied (1-54-see Appendix 1) according to $X$-ray analysis

stoichiometry and its petrographic features (and origin) was encountered. Microprobe study showed that most dolomite crystals do not contain detectable $\mathrm{Fe}$ and $\mathrm{Mn}$ admixtures that have been recorded only in rare crystals of one dolomite generation characterized by banded structure.

\section{PETROGRAPHY}

The Zechstein Limestone deposits were originally composed of calcite (mostly high-Mg) and partly aragonite (a part of bioclasts and synsedimentary cements). Primary calcite is rare; when present, it builds perfectly preserved bioclasts and cements, thus the diagenetic transformation was restricted in such cases to high-Mg $\rightarrow$ low-Mg calcite transformation. Most deposits, however, experienced intense diagenesis, and the dolomitisation and dolomite cementation were the most important processes. In addition, dedolomitisation, several phases of calcite cementation, anhydrite cementation and anhydritisation as well as authigenic mineral formation were recorded (Figs. 6-12). 


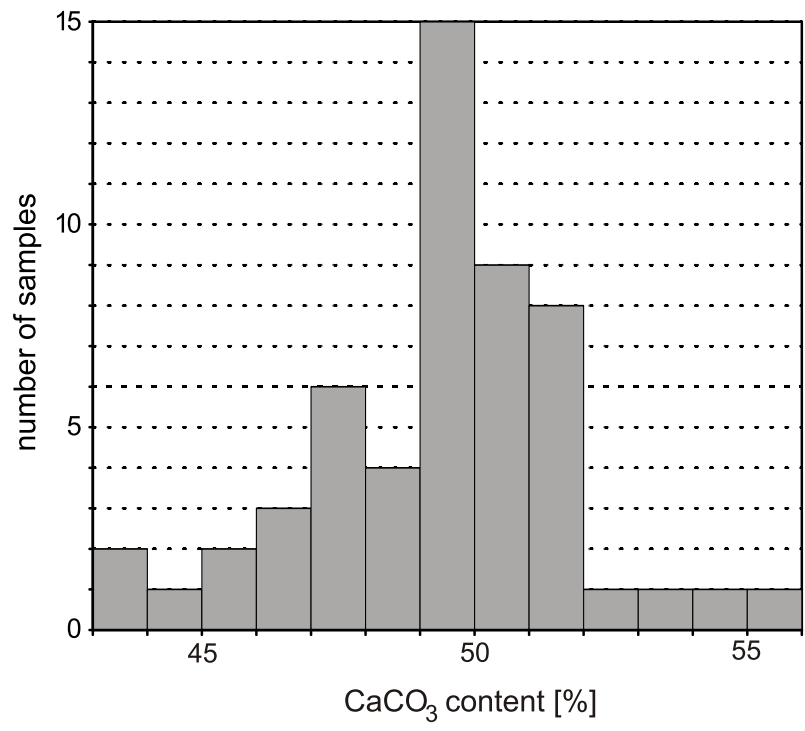

Fig. 5. Histogram of $\mathrm{CaCO}_{3}$ content in dolomite samples (1-54 - see Appendix 1)

There are two main types of dolomite in the Zechstein Limestone: replacement dolomite (mostly unimodal dolosparite mosaic that is mainly fabric-destructive) and cement dolomite. Both types show two basic textural types: non-planar and pla- nar (both subhedral and euhedral) (Sibley and Gregg, 1987), and the latter are clearly predominant.

Planar dolomites are composed of transparent crystals of clear rhomb cross-section with a size of several tens of micrometers. They occur throughout the entire Zechstein Limestone section and form usually isopachous rims on bioclasts and pore walls (Figs. 6, 7D, 9D and 11D). This cement generation follows the synsedimentary calcite cements and precedes blocky and other coarse-crystalline calcite cements and non-planar dolomite cement (saddle dolomite). The latter is composed of dark (due to abundant inclusions) centre and clear outer zones (Fig. 11), and is characterized by fan-shaped extinction and, in the case of euhedral habit, also by curved crystal walls. They do not show luminescence due to a high Fe content. Saddle dolomite is rare, and it usually fills large pores or joints, fully (monocrystals) or partly (druse-like aggregates).

There occur three varieties of replacement dolomite in the Zechstein Limestone: dolomicrite, fine to medium-crystalline dolosparite, and dolosparite. The latter is rare and the first two varieties are ubiquitous, being end-members of a continuum.

Dolomicrite is characterized by very fine- or cryptocrystalline texture. In some cases it underwent a clear recrystallisation that resulted in a unimodal mosaic of rhomb planar euhedral dolomite crystals (several tens of micrometres across). Dolomicrite occurs in sabkha and in pisolithic deposits of the uppermost unit of the Zechstein Limestone (Fig. 11), as well as in part strongly dolomitised wackestones, packstones and grainstones forming units (iii) and (iv), both in the matrix and the mimetically dolomitised bioclasts and other grains (Figs. 8A-D and 10A-D).
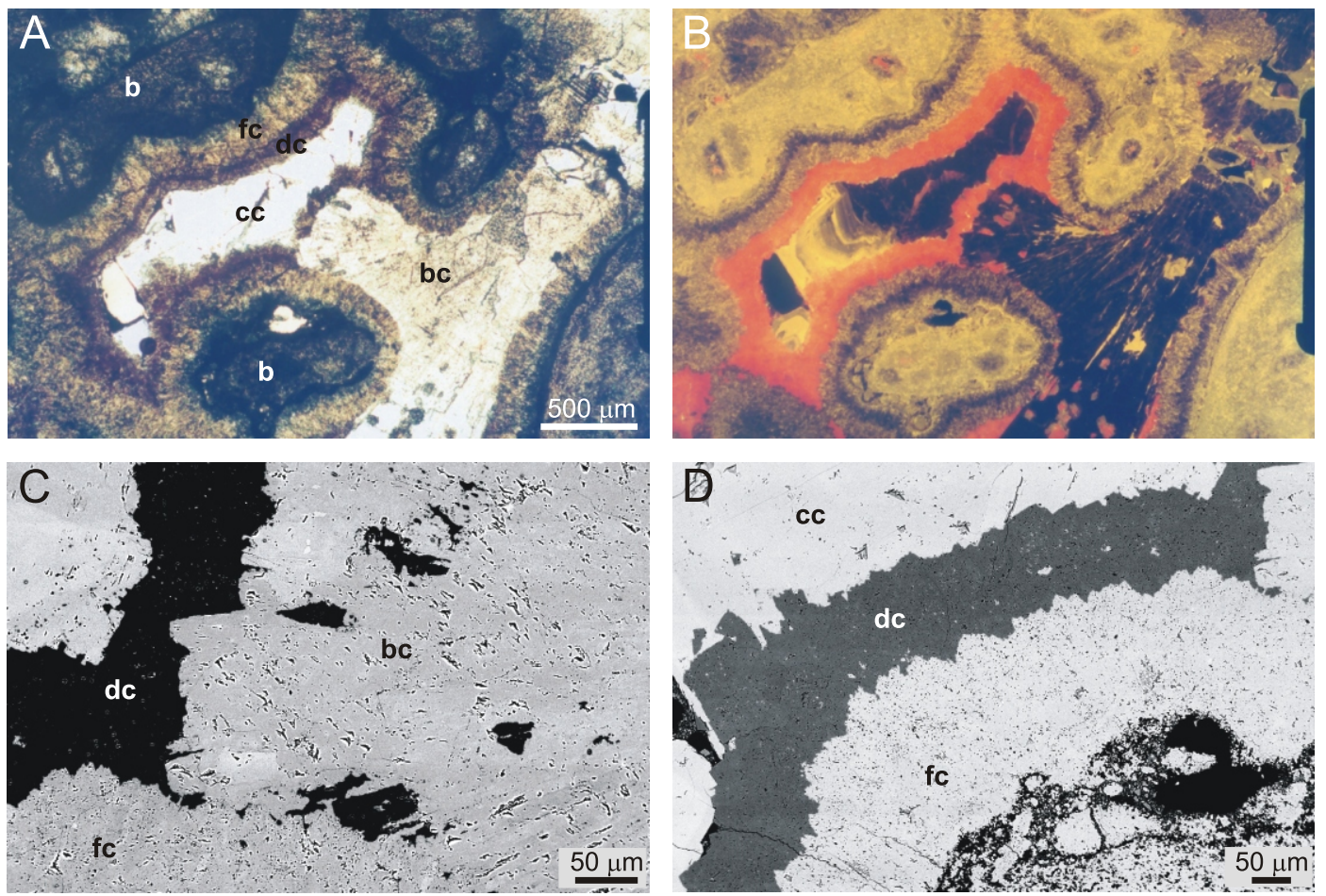

Fig. 6. Bryozoan grainstone (b-bryozoan) with several generations of carbonate cement

The two first generations are syndepositional marine cements forming isopachous rims (fc) and botryoidal cement (bc) of most probably primary aragonitic mineralogy. The next cement generation is isopachous rim dolomite (dc) intensely red in CL. Individual dolomite rhombs occur also within the botryoidal fabric. The last generation is coarsely crystalline calcitic sparry cement (cc) showing zoned structure in CL that is also subtly expressed in BS, indicating delicate differences in chemical composition (probably a greater Mn admixture) indistinguishable in microprobe study. Kościan 10, sample 34; A - plane polarized light; B - CL; C, D - backscattered electron image (BS) of a scanning electron microscope thin section 

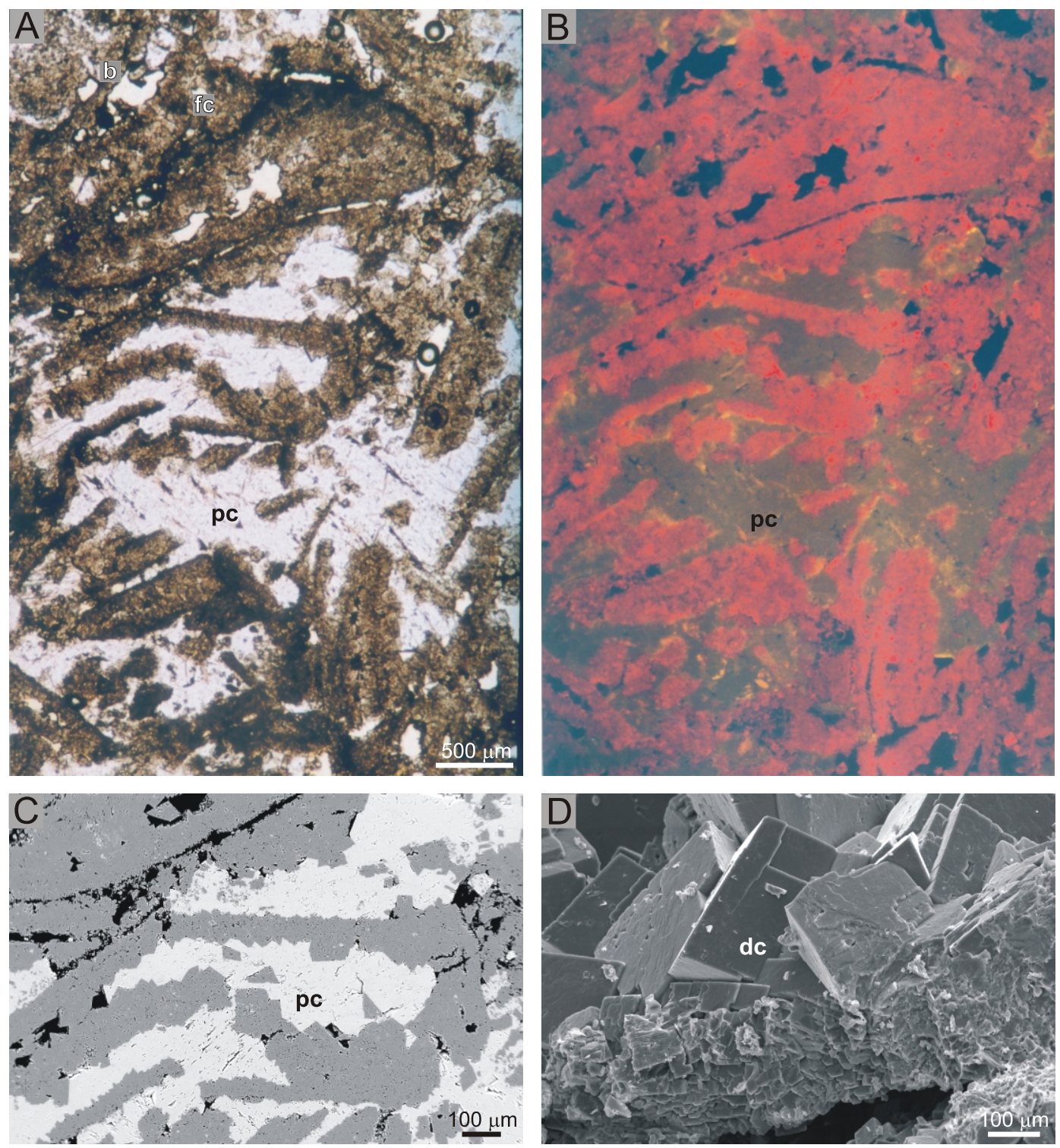

Fig. 7. Fully dolomitised bioclastic grainstone; the primary bioclast structures are obliterated due to fabric-destructive dolomitisation

Dolomitised bioclasts are made of fine dolomite crystals and coated by larger dolomite cement crystals (dc) showing euhedral forms. Dolomite is intensely red in CL; the pore space filled with poikilitic calcite cement (pc). Part of the porosity (black areas in CL and BS images) is primary and part is secondary (due to dissolution of bioclasts). Paproć 29, sample 74

A - plane polarized light; B - CL; C - backscattered electron image (BS) of a scanning electron microscope thin section; D - SEM photo

Those dolomites could have originated both in near-surface conditions (early diagenetic dolomitisation related to the sabkha zone), and during burial diagenesis.

Fine- and medium-crystalline dolosparite is usually developed in the form of a unimodal planar mosaic with abundant inclusions of crystals several tens of micrometres across. It originated due to the replacement of calcite, forming bioclasts and micritic deposits which destroyed the primary texture (fabric-destructive dolomitisation). It is common in units (ii), (iii), (iv) (fully dolomitised grainstones, packstones and wackestones) (Figs. 7 and 9) and within recrystallised deposits of unit (v) (Fig. 12C, D). Under cathodoluminescence almost all these dolomites show an intense red colour and rarely orange or yel- low-green colours that are activated by Mn (Habermann et al., 1996). The length of the emitted waves (and thus the colour) depends on the position of $\mathrm{Mn}$ ions in the crystal lattice. If it substitutes $\mathrm{Mg}^{2+}$ ions, which is the most common case, dolomite shows a red colour, and the position of the maximum of emission spectrum at about $660 \mathrm{~nm}$ wavelength. More rare yellow or orange colours are due to the occurrence of $\mathrm{Mn}^{2+}$ ions in the position of $\mathrm{Ca}^{2+}$ ions leading to the overlapping of the spectrum coming from the Ca-replacing Mn (maximum of about $575 \mathrm{~nm}$ ) over the maximum of $660 \mathrm{~nm}$ (Mg-replacing Mn) (Habermann et al., 1996). However, microprobe study did not show a detectable content of trace elements (including Mn). 

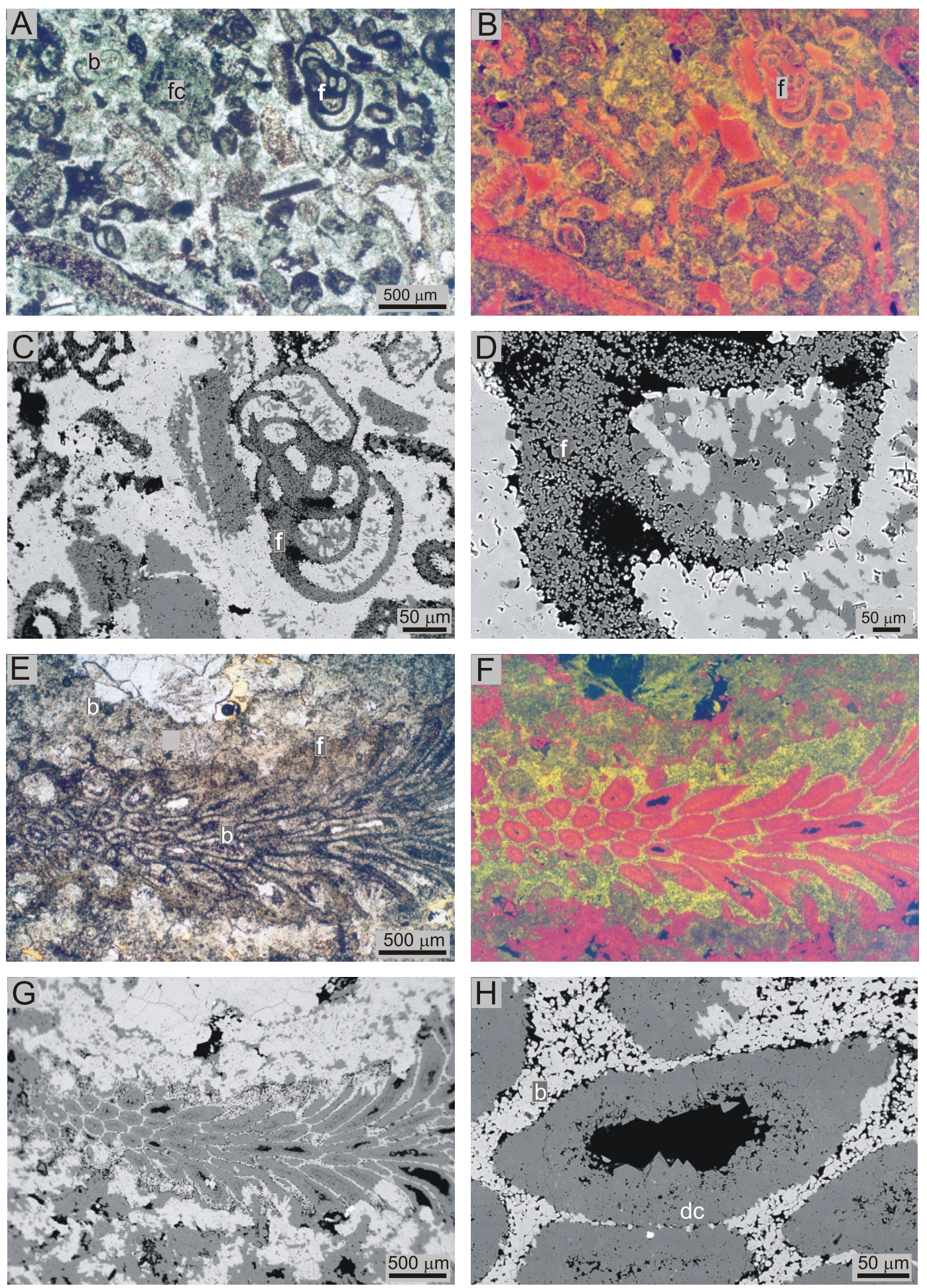

Fig. 8A-D - bioclast-peloid grainstone. Dolomitised grains (red in $\mathrm{CL}$, dark grey in BS) occur within calcitic cement (yellow in CL, light grey in BS). Although the primary microstructures are fully recrystallised due to dolomitisation, their outlines are perfectly preserved ( $f$ - foraminifer). Paproć 29 , sample 72; $\mathrm{E}-\mathrm{H}$ - dolomitic-calcitic mosaic (in CL dolomite is intensely red and calcite is yellow-black in $\mathrm{CL}$ ) with calcitic bryozoan zoarium (b) filled by rim dolomite cement (dc). The zoarium is completely recrystallised; black are pores. Paproć 29, sample 55

A, E - crossed polars; B, F - CL; C, D, G, H - backscattered electron image (BS) of a scanning electron microscope in thin section 

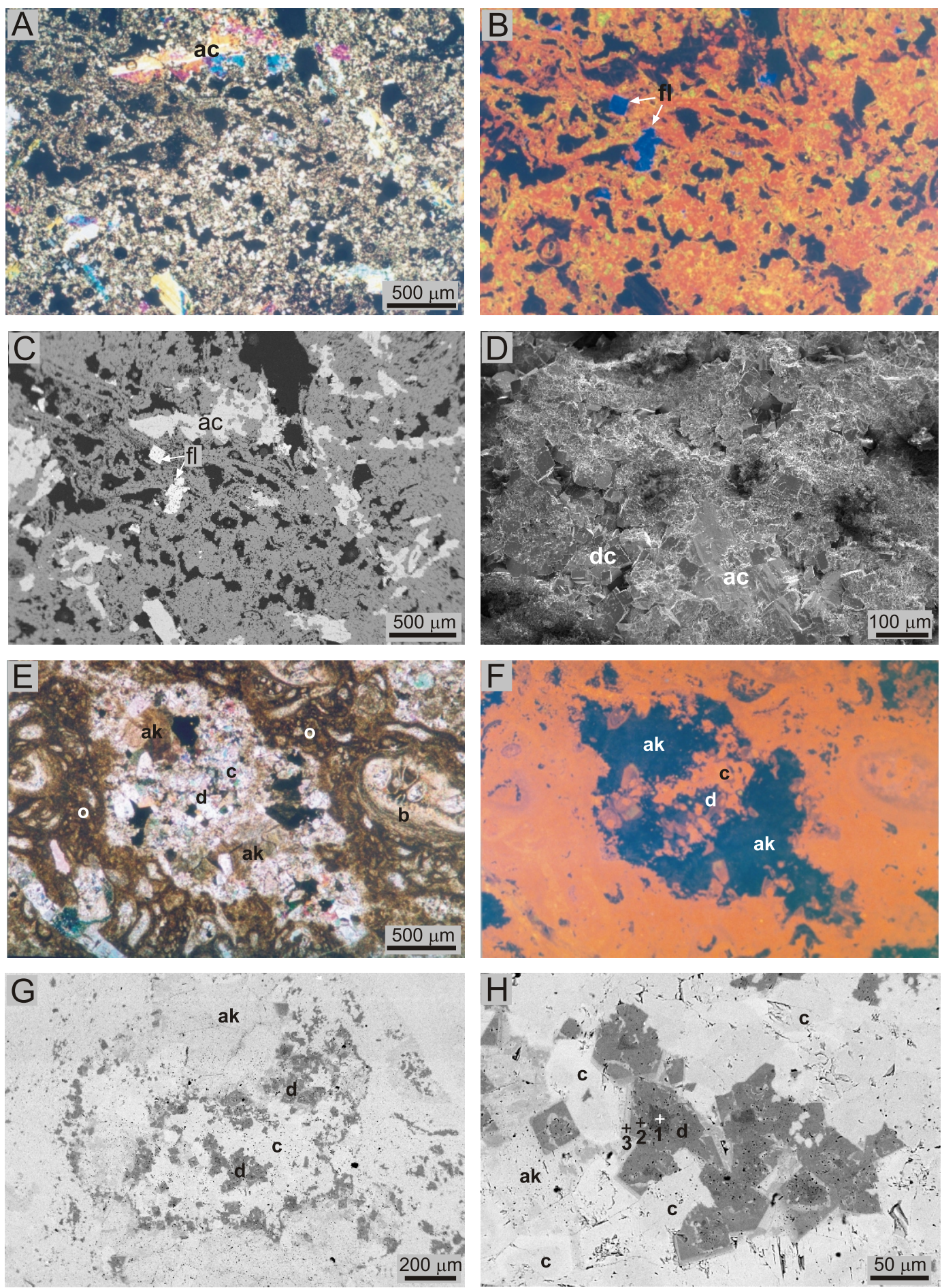

Fig. 9A-D - fully dolomitised bioclastic grainstone of obliterated primary structure of bioclasts, characterized by very high primary and secondary porosity, party destroyed by anhydrite cement (ac). Much of the dolomite shows yellow-free colours in CL; rare fluorite crystals (fl) show a blue colour. Dolomitised grains are coated by rhombohedral euhedral crystals of dolomite cement (dc); Paproć 29, sample 62; E-H - biolithite; Kościan 9, sample 32 (b-bryozoans, o - encrusting foraminifer). Cavern filled by ankerite-dolomite-calcite mosaic; ak - ankerite, $\mathrm{c}$ - calcite, $\mathrm{d}$-dolomite. Calcite shows a red colour in CL. Dolomite crystals show zoning in BS - outer parts of crystals are enriched in Fe and $\mathrm{Mn}$ and they are not bright in CL. Crosses 1-3 in D show places of analyses with microprobe

A, E - crossed polars; B, F-CL; C, G, H - backscattered electron image (BS) of a scanning electron microscope in thin section; $\mathbf{D}$ - SEM photo 

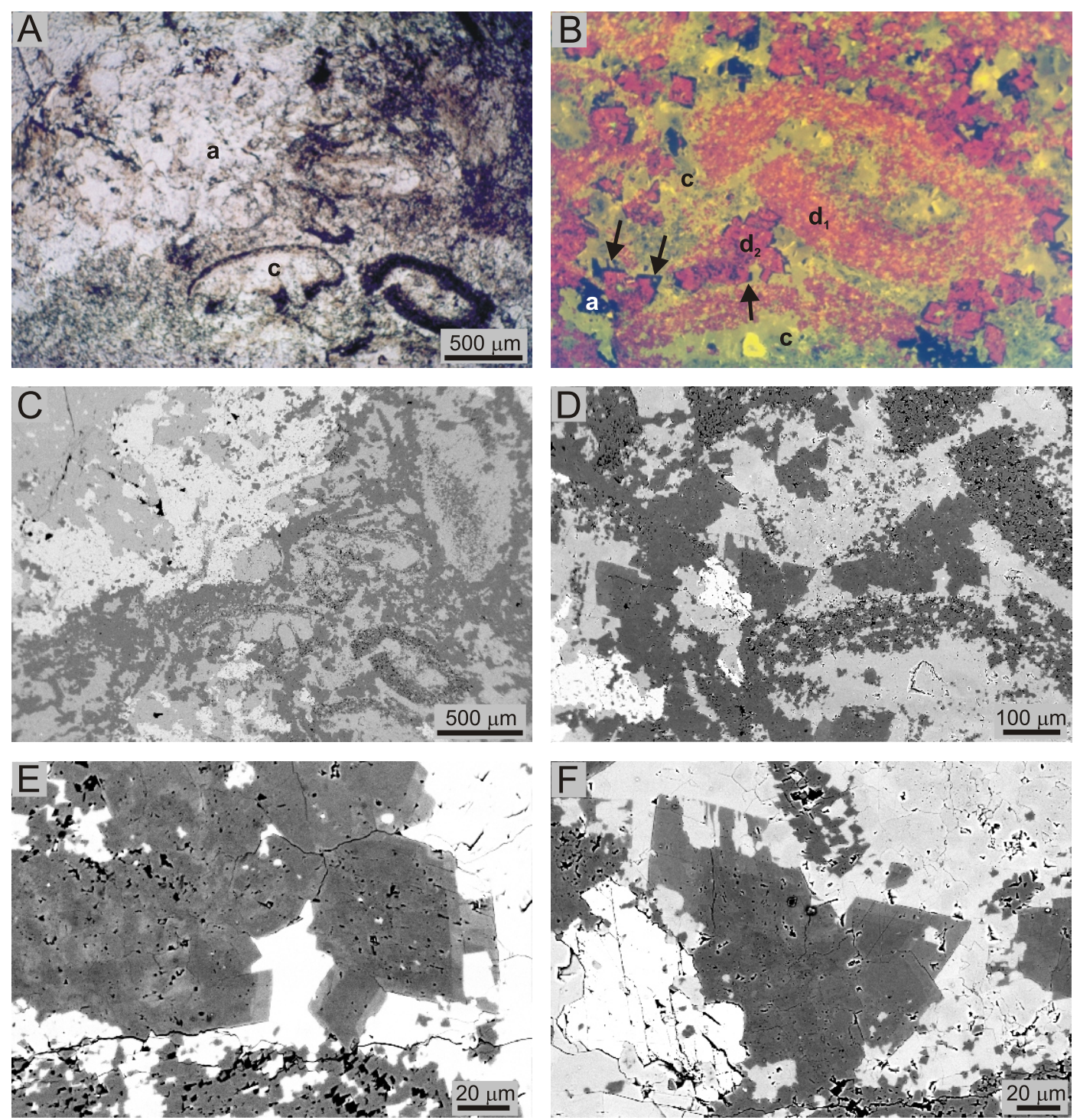

Fig. 10A-F - bioclastic grainstone, Paproć 21, sample 2-TMP; a - anhydrite, c - calcite, $d_{1}, d_{2}-$ dolomite. Outer (lighter) zones of dolomite $\left(d_{2}\right)$ crystals are enriched in $\mathrm{Fe}$ and $\mathrm{Mn}$ and they are not bright in CL (arrows); in places they are calcitised (yellow in CL and light in BS images)

A - plane polarized light; $\mathbf{B}-\mathrm{CL} ; \mathbf{C}-\mathbf{F}$ - backscattered electron image (BS) of a scanning electron microscope in thin section

Dolosparite of a banded structure usually comprises planar euhedral crystals several tens to ca. 100 micrometre across, individual or clustered in aggregates (Figs. $9 \mathrm{E}-\mathrm{H}$ and 10). They show opaque pore centres composed of luminescent pure dolomite, showing cathode luminescence, that are surrounded by a non-luminescent dolomite rim. This is the youngest dolomite generation occurring rarely in some sections, usually in their basal parts. In some cases these crystals are calcitised (Figs. 9H and 10E-F).

\section{STABLE ISOTOPE GEOCHEMISTRY}

The oxygen and carbon isotope composition of calcite and dolomite in the samples studied are listed in Table 1 and shown in Figures 3 and 13.
Measured values of $\delta^{13} \mathrm{C}$ of calcite and dolomite in the studied boreholes are in the ranges shown, except for one sample of calcite and dolomite, of about 0 to $+8 \%$ VPDB (average $+4.7 \%$ o for calcite and average $+5.13 \%$ for dolomite; Table 1 and Fig. 13). The $\delta^{18} \mathrm{O}$ values show even greater variation from about +3 to $-13 \%$ VPDB in calcite (average $-4.79 \%$ ) and from +3 to $-9 \%$ o VPDB in dolomite (average -3.99\%) (Table 1 and Fig. 13).

In the sections studied of the Zechstein Limestone, the vertical variations in the $\delta^{13} \mathrm{C}$ values and especially $\delta^{18} \mathrm{O}$ values are large, both in calcite and dolomite, but show a random pattern (Fig. 3), although a slight upward increase trend in $\delta^{13} \mathrm{C}$ values can be observed. In addition, the isotopic composition of oxygen is controlled to a greater extent by primary facies and diagenesis than by the isotopic composition of carbon. For example, the calcite mosaic at the base of the Zechstein Limestone in the borehole Paproć 29 is highly depleted and the 

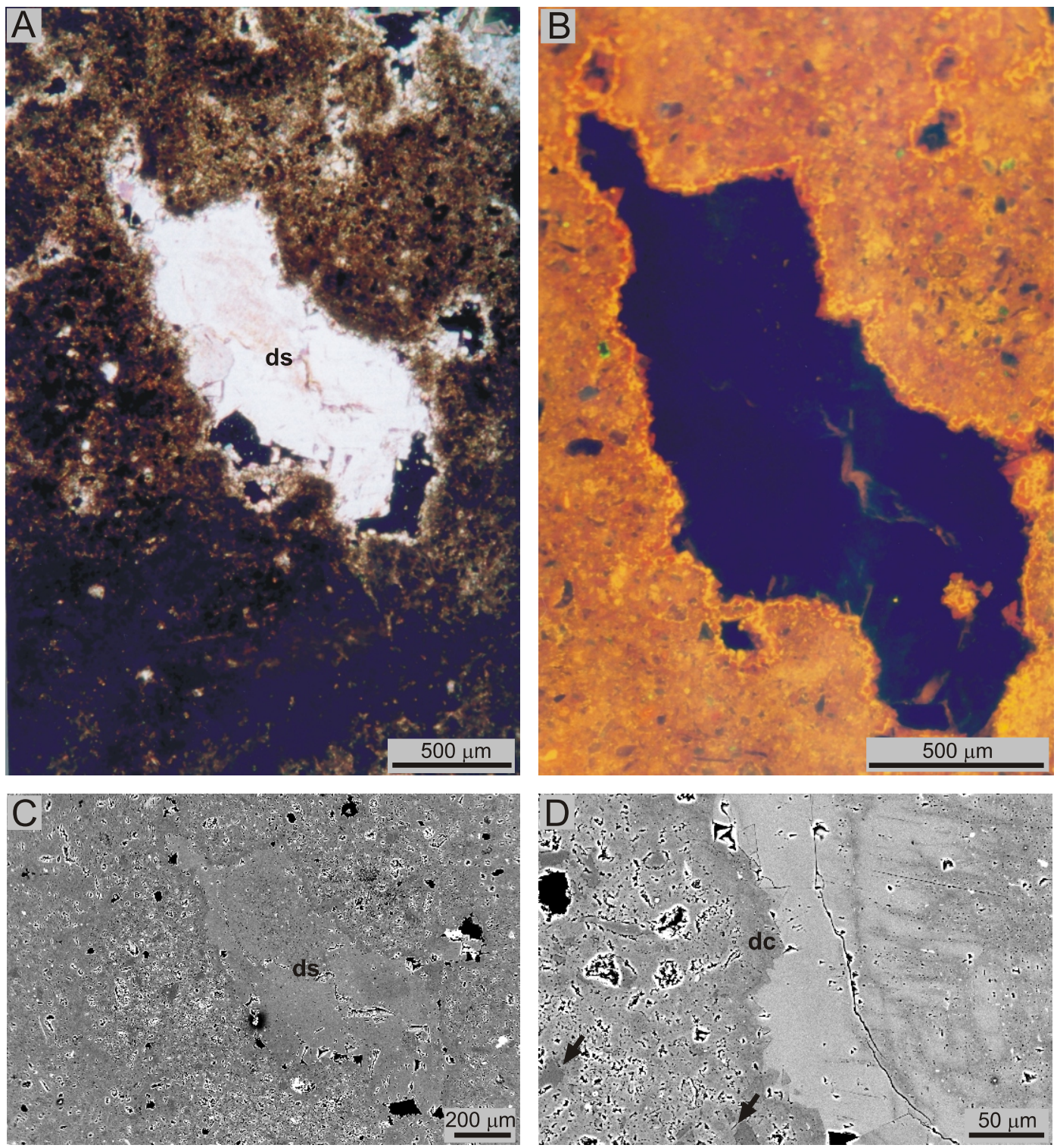

Fig. 11A-D - large pore in dolomicrite sabha deposits filled by monocrystal of saddle dolomite (ds). In the dolomicrite, common silt quartz occurs (darker sharp-edged fields in BS, see arrows in D). Dolomicrite is cryptocrystalline and only the walls of pores are rimmed by finely crystalline dolomite cement (dc). Kościan 10, sample 20

$$
\text { A - crossed polars; B - CL; C, D - SEM photos }
$$

dolomicritic sabkha deposits in the uppermost part of the Kościan 9 section are clearly rich in ${ }^{18} \mathrm{O}$, whereas their $\delta^{13} \mathrm{C}$ values differ only slightly (see Figs. 13 and 14A).

\section{INTERPRETATION AND DISCUSSION}

When the omnipresent anhydrite is ignored and only the carbonate composition is taken into consideration, most analysed samples of dolomite and all analysed samples of limestone are not $100 \%$ dolomite or $100 \%$ calcite, respectively. This implies that sharp limestone-dolomite contacts are rare, and this is supported by macroscopic observations. The geometry of replacement dolomite bodies can be complex, as this is a direct image of the geometry of dolomitising fluid flow paths (Wil- son et al., 1990) that in turn is controlled by the proximity to the brine source, zones of relatively higher porosity, and permeability contrasts, as indicated by Garcia-Fresca et al. (2012) for the Permian San Andres Formation (cf. Carmichael and Ferry, 2008; Carmichael et al., 2008; Al-Helal et al., 2012). In addition, complex limestone-dolomite distribution as observed in the Zechstein Limestone reefs resulted from multiple reflux events, both in time and space (cf. Garcia-Fresca et al., 2012).

The timing of the extensive dolomitisation and dolomite cementation are difficult to ascertain, but combined petrographical and isotopic geochemical data (e.g., dominance of planar and sparsity of nonplanar dolomites, relatively high $\delta^{18} \mathrm{O}$ values) indicates that the reef carbonates were dolomitised soon after deposition in a near-surface sabkha/seepage-reflux system. Calcite was mostly dolomitised in association with low-temperature 

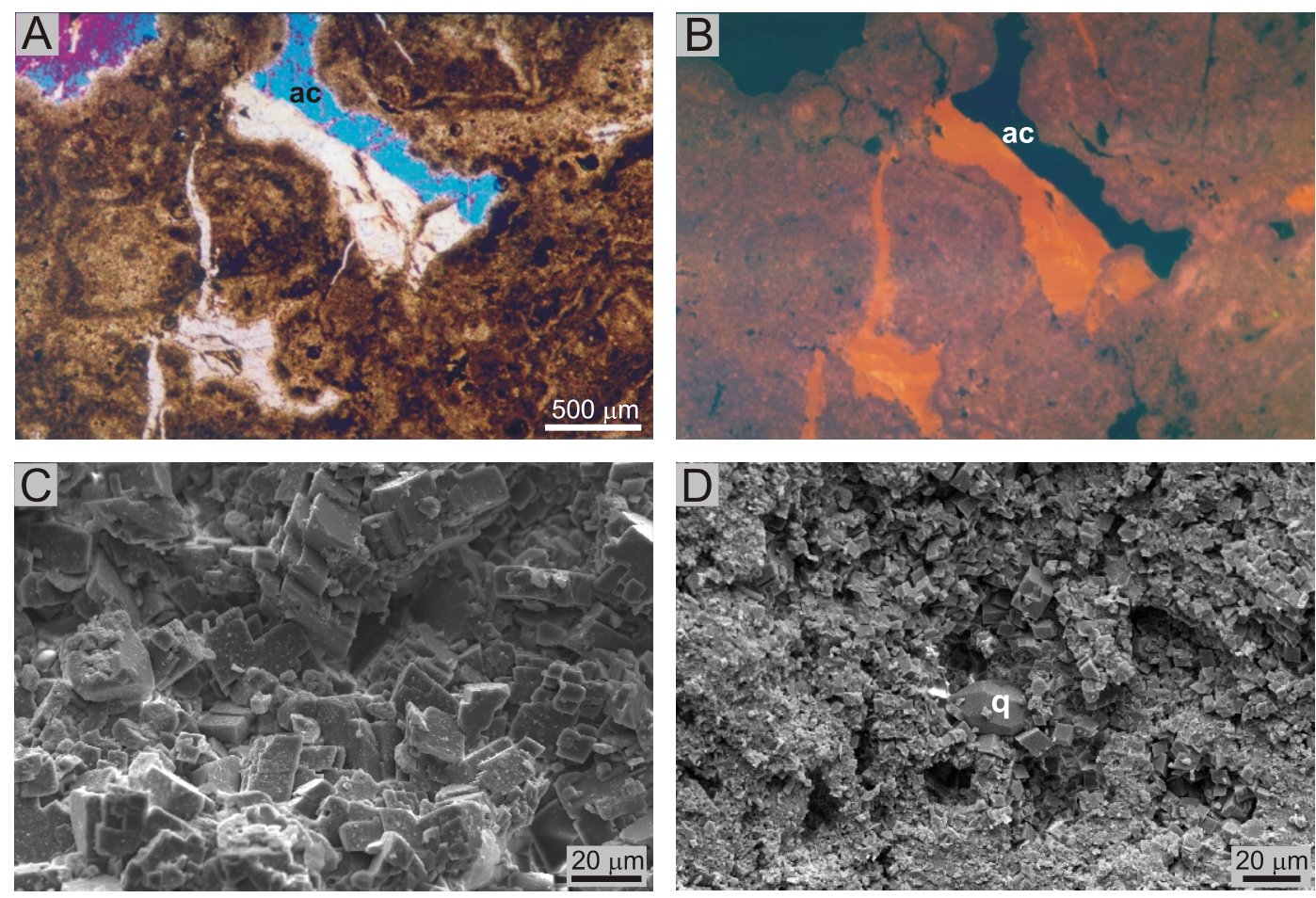

Fig. 12A, B - partly recrystallised vadoid grainstone; pores filled by calcite cement (red in $\mathrm{CL}$ ) and anhydrite cement (black in CL). Kościan 9, sample 16; C, D - sabkha dolomite composed of unimodal mosaic of fine dolomite crystal rhombs; slightly larger dolomite crystals occur in pores; $q$ - authigenic quartz, ac - anhydrite cement. Kościan 9, sample 13 (C), Kościan 19 (D)

$$
\text { A - crossed polars; B - CL; C, D - SEM photos }
$$

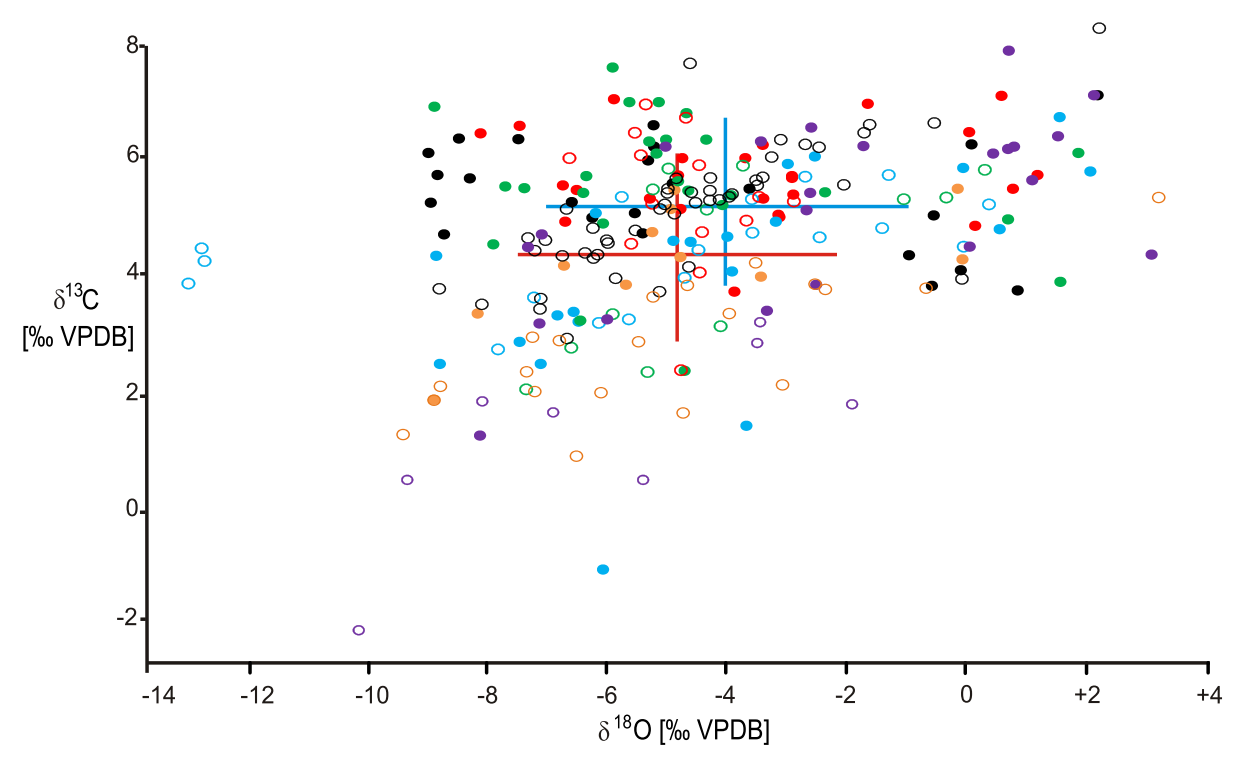

Brońsko 1 Kokorzyn 1 Kościan 9 Kościan 10 Paproć 21 Paproć 29

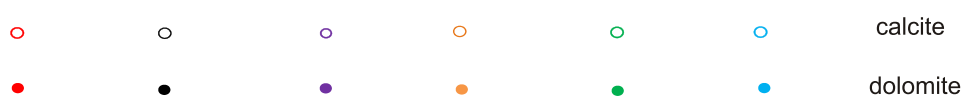

Fig. 13. Oxygen and carbon isotopes in the Zechstein Limestone (Ca1) deposits of the Wolsztyn High in the reef sections studied (Brońsko 1 after Dyjaczynski et al., 2001) 
Table 1

The oxygen and carbon isotope composition (in \%) of calcite and dolomite in the samples studied

\begin{tabular}{|c|c|c|c|c|c|c|c|}
\hline Borehole & Mineralogy & $\begin{array}{c}\text { Number of } \\
\text { analyses }\end{array}$ & $\begin{array}{c}\text { Minimum } \\
{[\% \text { ] }}\end{array}$ & $\begin{array}{c}\text { Maximum } \\
{[\% \text { ] }}\end{array}$ & $\begin{array}{c}\text { Mean } \\
{[\% 0]}\end{array}$ & $\begin{array}{c}\text { Mediane } \\
{[\% \circ]}\end{array}$ & $\begin{array}{c}\text { Standard } \\
\text { deviation } \\
{[\% 0]}\end{array}$ \\
\hline \multirow{4}{*}{ Brońsko 1} & calcite $-\delta^{13} \mathrm{C}$ & 20 & 2.34 & 6.94 & 5.39 & 5.36 & 1.01 \\
\hline & calcite $-\delta^{18} O$ & 20 & -6.62 & -1.8 & -4.26 & -4.43 & 1.19 \\
\hline & dolomite $-\delta^{13} \mathrm{C}$ & 25 & 3.7 & 7.09 & 5.71 & 5.67 & 0.79 \\
\hline & dolomite $-\delta^{18} \mathrm{O}$ & 25 & -8.1 & 1.18 & -3.57 & -3.4 & 2.64 \\
\hline \multirow{4}{*}{ Kokorzyn 1} & calcite $-\delta^{13} \mathrm{C}$ & 48 & 2.89 & 8.26 & 5.11 & 5.22 & 1.08 \\
\hline & calcite $-\delta^{18} O$ & 48 & -8.79 & 2.21 & -4.68 & -4.86 & 2.15 \\
\hline & dolomite $-\delta^{13} \mathrm{C}$ & 23 & 3.72 & 7.1 & 5.4 & 5.48 & 0.91 \\
\hline & dolomite $-\delta^{18} \mathrm{O}$ & 23 & -8.97 & 2.18 & -4.64 & -5.31 & 3.59 \\
\hline \multirow{4}{*}{ Kościan 9} & calcite $-\delta^{13} \mathrm{C}$ & 8 & -2.16 & 3.17 & 1.23 & 1.68 & 1.68 \\
\hline & calcite $-\delta^{18} O$ & 8 & -10.13 & -1.91 & -6.08 & -6.14 & 3.0 \\
\hline & dolomite $-\delta^{13} \mathrm{C}$ & 22 & 1.21 & 7.87 & 5.18 & 5.52 & 1.57 \\
\hline & dolomite $-\delta^{18} \mathrm{O}$ & 22 & -8.11 & 3.085 & -2.23 & -2.55 & 3.41 \\
\hline \multirow{4}{*}{ Kościan 10} & calcite $-\delta^{13} \mathrm{C}$ & 20 & 0.85 & 5.33 & 2.80 & 2.84 & 1.14 \\
\hline & calcite $-\delta^{18} \mathrm{O}$ & 20 & -9.39 & 3.2 & -5.06 & -5.34 & 3.05 \\
\hline & dolomite $-\delta^{13} \mathrm{C}$ & 11 & 1.83 & 5.48 & 4.22 & 4.26 & 1.05 \\
\hline & dolomite $-\delta^{18} \mathrm{O}$ & 11 & -8.88 & -0.07 & -4.81 & -4.93 & 2.80 \\
\hline \multirow{4}{*}{ Paproć 21} & calcite $-\delta^{13} \mathrm{C}$ & 12 & 2.01 & 5.88 & 4.35 & 5.21 & 1.52 \\
\hline & calcite $-\delta^{18} O$ & 12 & -7.34 & 0.3 & -4.05 & -4.65 & 2.46 \\
\hline & dolomite $-\delta^{13} \mathrm{C}$ & 25 & 2.33 & 7.58 & 5.57 & 5.52 & 1.20 \\
\hline & dolomite $-\delta^{18} \mathrm{O}$ & 25 & -8.87 & 1.86 & -4.74 & -5.13 & 2.70 \\
\hline \multirow{4}{*}{ Paproć 29} & calcite $-\delta^{13} \mathrm{C}$ & 18 & 2.7 & 5.72 & 4.41 & 4.46 & 0.88 \\
\hline & calcite $-\delta^{18} \mathrm{O}$ & 18 & -12.97 & 0.37 & -5.27 & -4.58 & 4.15 \\
\hline & dolomite $-\delta^{13} \mathrm{C}$ & 21 & -1.11 & 6.72 & 4.05 & 4.56 & 1.82 \\
\hline & dolomite $-\delta^{18} \mathrm{O}$ & 21 & -8.84 & 2.06 & -4.28 & -4.6 & 3.20 \\
\hline \multirow{4}{*}{ TOTAL } & calcite $-\delta^{13} \mathrm{C}$ & 126 & -2.16 & 8.26 & 4.37 & 4.64 & 1.63 \\
\hline & calcite $-\delta^{18} \mathrm{O}$ & 126 & -12.97 & 3.20 & -4.79 & -4.72 & 2.65 \\
\hline & dolomite $-\delta^{13} \mathrm{C}$ & 127 & -1.11 & 7.87 & 5.13 & 5.41 & 1.39 \\
\hline & dolomite $-\delta^{18} \mathrm{O}$ & 127 & -8.97 & 3.08 & -3.99 & -4.74 & 3.16 \\
\hline
\end{tabular}

seepage reflux during deposition of the overlying PZ1 sulphate deposits. This process was accompanied by anhydrite precipitation (cf. Rahimpour-Bonab et al., 2010).

This dolomitisation was usually fabric-selective, or at least fabric-retentive, as is common for low-temperature dolomite (Machel, 2004). In contrast, high-temperature dolomitisation is mostly fabric-destructive (cf. Machel, 2004). Machel (2004) concluded that dolomites that originally form very close to the surface and from evaporitic brines tend to recrystallise with time and during burial, and the case studied fully supports such a conclusion. This early dolomite (either of sabkha or reflux origin) was extensively recrystallised during burial with neomorphism and formation of fabric-destructive dolomites, and dolomite cement precipitated from highly saline, hot waters during Late Permian to Triassic times that were character- ized by higher heat flow, that subsequently decreased during the Early Jurassic to Late Cretaceous (Karnkowski, 1999; Kotarba et al., 2006).

The isotopic composition of dolomites may actually reflect a gross representation of the chemistry of recrystallising fluids, rather than the composition of the original fluids (e.g., Land, 1985; Hardie, 1987), and therefore diagenetic stabilization after multiple periods of dolomitisation produces complex dolomite textures and chemical compositions (Gao and Land, 1991; Gregg et al., 2001; El-Tabakh et al., 2004).

Very positive carbon isotopic values recorded in the Zechstein Limestone are typical of Permian dolomites of marine provenance ( $\delta^{13} \mathrm{C}$ values about $+4 \%$ PDB - Scholle, 1995) and are probably related to changes in the burial rate of organic carbon during this period (Scholle, 1995). Those values indicate 


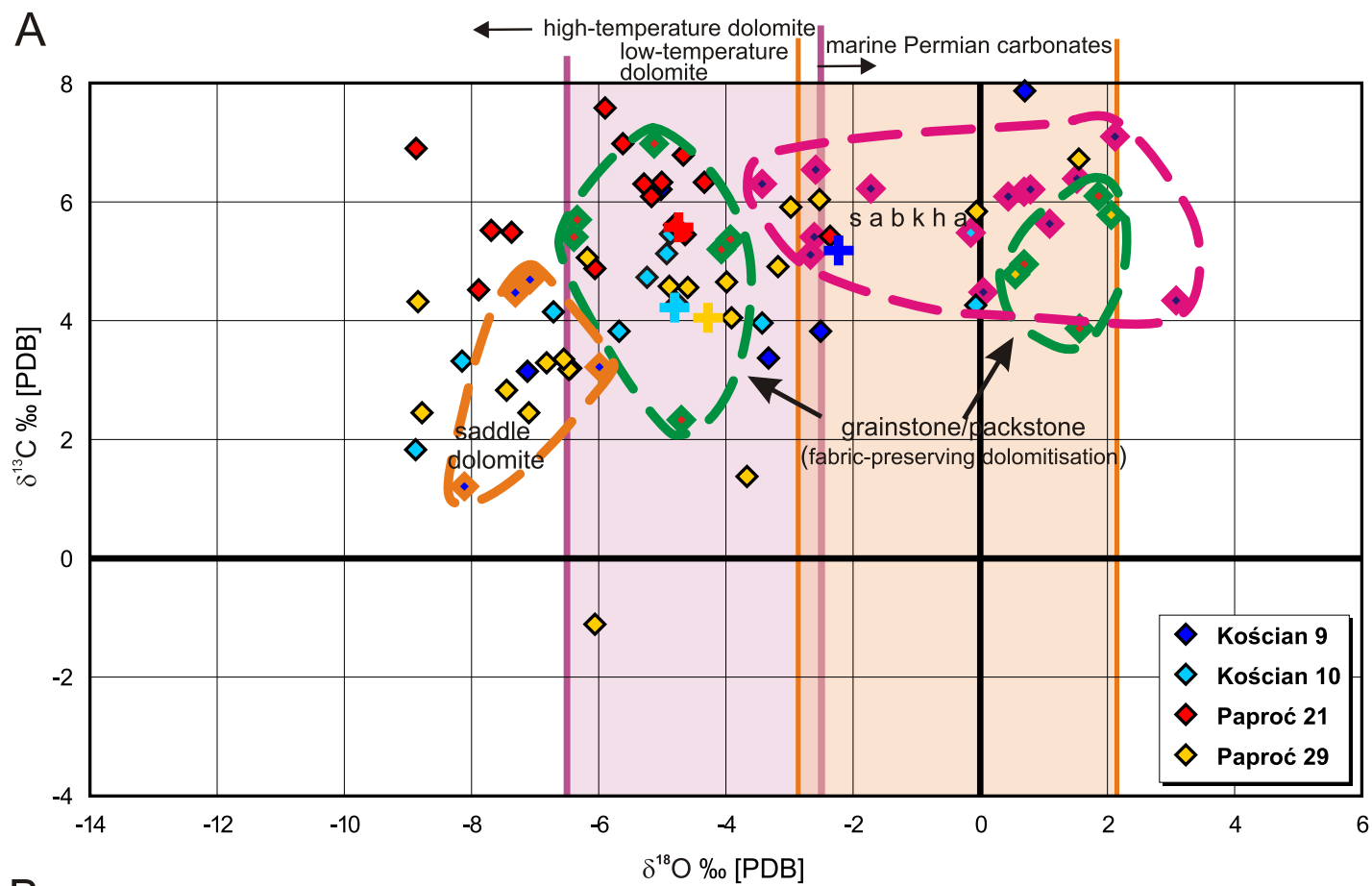

B

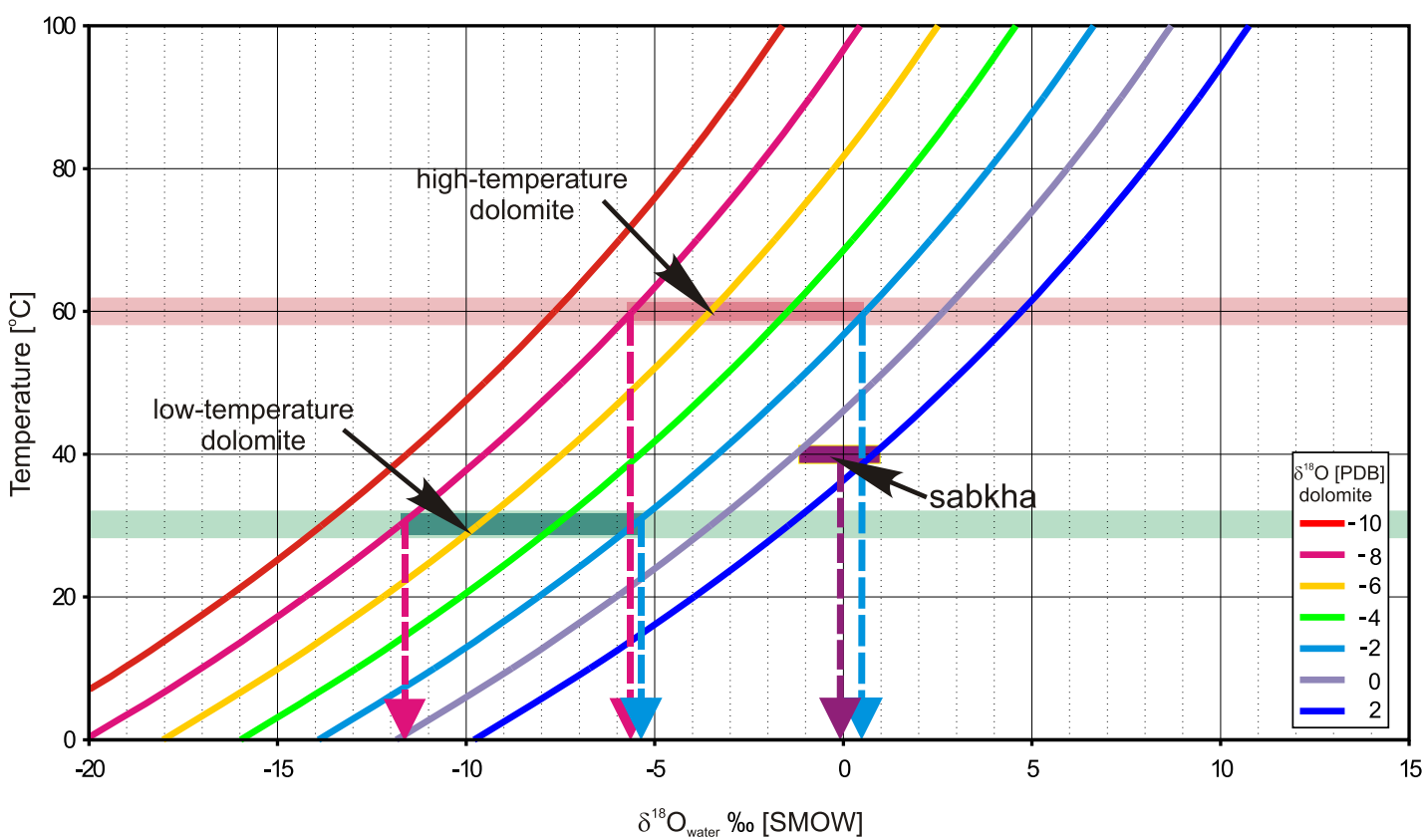

Fig. 14A - oxygen and carbon isotopes in the dolomites of the Zechstein Limestone of the Wolsztyn reefs set against the $\delta^{18} \mathrm{O}$ values of low- and high-temperature dolomites and Permian marine carbonates (after Allan and Wiggins, 1993); B - interpretation of oxygen isotopes in dolomites of the Zechstein Limestone of the Wolsztyn Ridge

The curves are according to the equation $\delta^{18} \mathrm{O}_{\text {dol. }}-\delta^{18} \mathrm{O}_{\text {water }}=\left[3.2 \times 10^{6} \mathrm{~T}^{-2}\right]-1.5$ (Friedman and O'Neil, 1977)

that the basic source for carbonate ions during diagenesis was the Zechstein Limestone deposits, and therefore the diagenetic system was closed as far as the carbon is concerned. Most measured values of $\delta^{13} \mathrm{C}$ of calcite and dolomite overlap in the range $2-3 \%$ and thus it is assumed that in most cases the carbon isotope composition of replacement dolomite was inherited from its calcite (Table 1).
A broad range of $\delta^{18} \mathrm{O}$ values was found in the dolomites, corresponding to both the low- and high-temperature dolomites (Fig. 13). Two groups of dolomite can be distinguished (Fig. 14A).

The first group are laminated or structureless and cavernous sabkha dolomicrites with anhydrite and pisolithic deposits that were syndepositionally dolomitised in the sabkha environ- 
ment by solutions enriched in ${ }^{18} \mathrm{O}$ due to evaporation. The $\delta^{18} \mathrm{O}$ values are from 0 to $+3 \%$ VPDB. Assuming a crystallisation temperature of $40^{\circ} \mathrm{C}$, sabkha deposits originated from water characterized by $\delta^{18} \mathrm{O}$ values close to $0 \%$ SMOW, which corresponds to slightly evaporated ice-free Late Permian seawater (Chen et al., 2013). Depending on the temperature, an uncertainty in $\delta^{18} \mathrm{O}$ of fluid of $\pm 1 \%$ o translates into an uncertainty in the temperatures recorded by $\delta^{18} \mathrm{O}$ of calcite or dolomite of \pm 5 to $\pm 8^{\circ} \mathrm{C}$ (Carmichael and Ferry, 2008).

A part of the isotopically heavier deposits is also represented by dolomitised grainstones showing perfectly preserved primary fabric (fabric-preserving dolomitisation; Fig. 14A). These dolomites might have originated through dolomitisation in the sabkha environment or through reflux.

Other dolomites, independently of primary facies and diagenesis intensity, show low $\delta^{18} \mathrm{O}$ values (from -2 do $-10 \%$ VPDB) that often are located within the field of interfingering of low- and high-temperature dolomites (Fig. 14A) and thus it is difficult to conclude their origin. Assuming that dolomites have low-temperature provenance (for example, they originated in the mixing zone), the $\delta^{18} \mathrm{O}$ values of water should be very low (in some cases around $-10 \%$ PDB - see Fig. 14B). This seems to be improbable, even if the isotopic composition of Late Permian sea water was slightly lighter and the Earth surface temperatures were much higher than they are today (Chen et al., 2013; Schobben et al., 2014). In turn, if crystallisation at a higher temperature is accepted, the $\delta^{18} \mathrm{O}$ values are more realistic. Therefore it seems that most of the dolomites gained their present isotopic composition in burial conditions at relatively high temperatures (see Fig. 14B), and such a conclusion is supported by the presence of saddle dolomite that is characteristic for deeply buried conditions with temperatures ranging from 60 to $150^{\circ} \mathrm{C}$ (Radke and Mathias, 1980). However, the most common petrographic texture of dolomite is planar, typical of low-temperature diagenetic environments (Sibley and Gregg, 1987) although Wright et al. (2004) deduced, for the Lower Carboniferous of Ireland, that planar replacement dolomite can be produced by modification of sea water by an increase in temperature to a minimum of $50^{\circ} \mathrm{C}$ and a maximum of $70^{\circ} \mathrm{C}$, and thus was inherited after earlier, low-temperature phases of dolomite formation. Jones (2005) showed that the development of planar as opposed to non-planar boundaries of dolomite crystals is not always dependent on the critical roughening temperature. The number of major dolomitisation phases is difficult to ascertain.

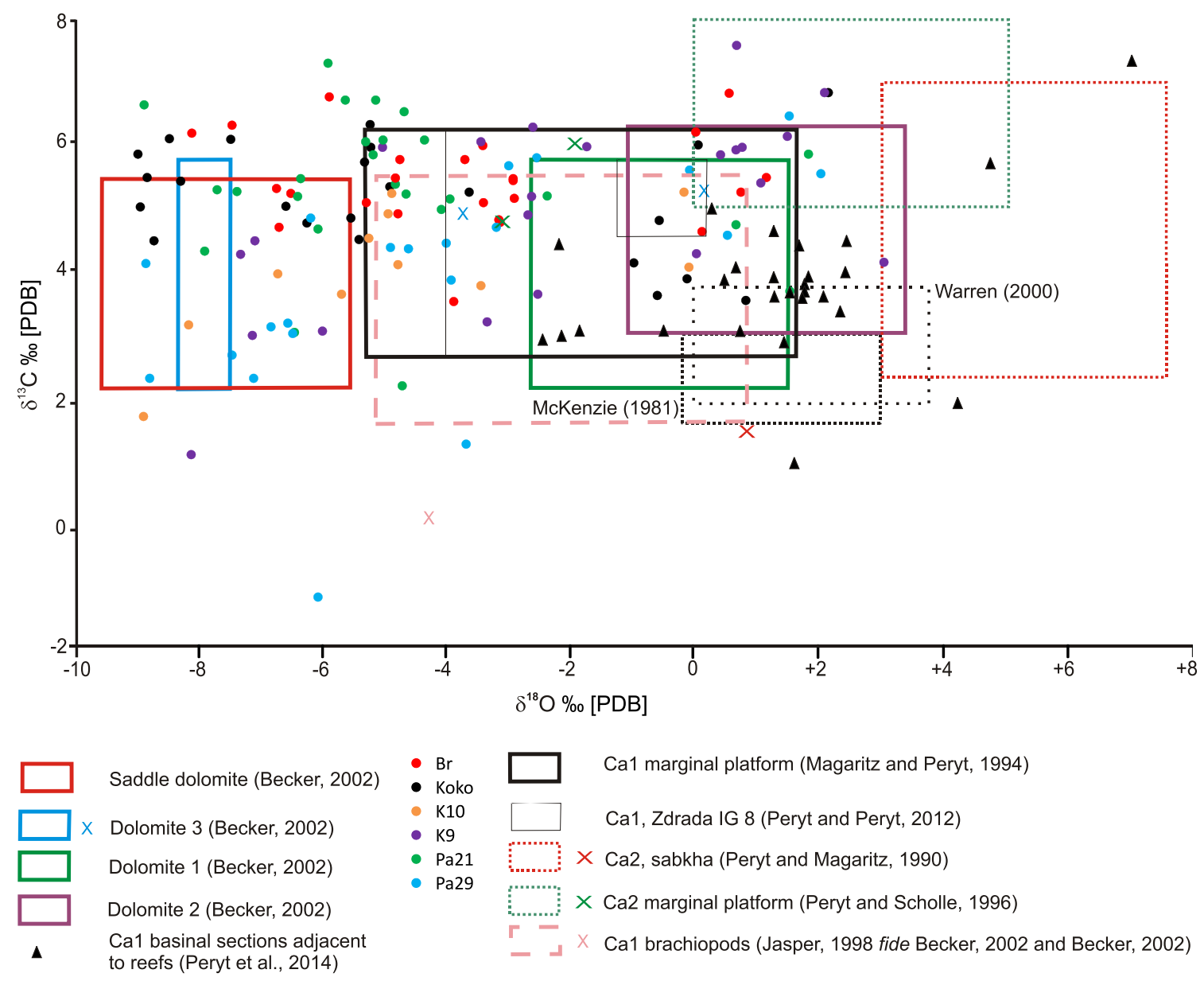

Fig. 15. The plot of $\delta^{13} \mathrm{C}$ and $\delta^{18} \mathrm{O}$ values for the Zechstein Limestone in SW Poland and some data from the other parts of the Zechstein Basin (after Peryt and Magaritz, 1990; Magaritz and Peryt, 1994; Peryt and Scholle, 1996; Becker, 2002; Peryt and Peryt, 2012) including data on brachiopods (after Becker, 2002)

The spread of data is shown by fields supplemented by the location of individual samples showing divergent values (these are marked by ' $X$ '); data on recent Abu Dhabi sabkha deposits (after McKenzie, 1981, and Warren, 2000) are shown as well 
The dolomites studied show a much greater range of $\delta^{18} \mathrm{O}$ values and a slightly greater range of $\delta^{13} \mathrm{C}$ values than dolomites from the marginal carbonate platform of the Zechstein Limestone in SW Poland (Fig. 14), and at the same time a similar range of $\delta^{18} \mathrm{O}$ values and slightly greater range of $\delta^{13} \mathrm{C}$ values than dolomites from the Hessian Zechstein characterized by Becker (2002). He distinguished four types of dolomites, based on petrography, cathodoluminescence, trace elements and carbon and oxygen isotope data:

- dolomite 1 formed in a sabkha environment and characterized by $\delta^{18} \mathrm{O}$ values ranging from -2.4 to $1.5 \%$;

- dolomite 2 formed due to brine-reflux during deposition of the Lower Werra Anhydrite - it shows $\delta^{18} \mathrm{O}$ values from -0.8 to $3.4 \%$;

- dolomite 3 formed during shallow burial dolomitisation, with $\delta^{18} \mathrm{O}$ values from -8.2 to $0.3 \%$; and the youngest;

- saddle dolomite, with $\delta^{18} \mathrm{O}$ values from -5.7 to $-9.3 \%$ (Becker, 2002; Fig. 15).

$\delta^{18} \mathrm{O}$ values of the dolomites from three basinal sections located close to the reefs studied (Paproć 28, Kościan 21 and Czarna Wieś 4 - Peryt et al., 2014) range from -2.4 to $7.1 \%$ o and $\delta^{13} \mathrm{C}$ values are from 1 to $7.2 \%$; thus their ranges are smaller. The basinal dolomites show higher $\delta^{18} \mathrm{O}$ values compared to the reef sections (Fig. 14; Peryt et al., 2014).

The dolomites of the isolated reefs differ from the dolomites in reefs related to the marginal carbonate platform in that the latter are mostly stoichiometric and well ordered (Magaritz and Peryt, 1994). Evaporitic dolomites tend to be more stoichiometric (Lumsden and Chimahusky, 1980). Kaczmarek and Sibley (2011) concluded that dolomite does not evolve towards more stoichiometric composition, but instead, more stoichiometric dolomite was formed in solutions with higher $\mathrm{Mg} / \mathrm{Ca}$.

\section{CONCLUSIONS}

1. The Zechstein Limestone sections of the Wolsztyn High are usually of a mixed mineralogical composition and represent a continuous spectrum from pure limestone to pure dolomite. This is due to varying degrees of dolomitisation, dolomite cementation and dedolomitisation. Dolomitisation was the main diagenetic process and it was accompanied by dolomite cementation ("over-dolomitisation").

2. Both main types of dolomite, replacement dolomite and cement dolomite, show two basic textural types: non-planar and planar (both subhedral and euhedral).

3. Petrographical and geochemical data indicate that the reefs were dolomitised shortly after deposition in a near-surface sabkha/seepage-reflux environment, probably from cumulative short-lived events, and then in burial conditions.

4. The present isotopic composition of dolomites was controlled by relatively high-temperature burial conditions as shown by quite low oxygen isotopic ratios $\left(\delta^{18} \mathrm{O}\right.$ as low as $-9 \%$ PDB) and the presence of saddle dolomite. There is no isotopic evidence for mixing-water dolomitisation.

Acknowledgements. The research was funded by the State Committee for Scientific Research (Grant No. 9 T12B 028 15 to TMP) and the statutory funds of the PGI-NRI (project No. 6.20.1382.00.0 to MJ). TD was supported by the U.S. Department of Energy, Office of Science, Basic Energy Sciences, Materials Sciences and Engineering Division. The Polish Oil and Gas Company granted access to core material and thin sections. A. Wójtowicz helped with the analyses, and K. Chłódek offered logistical support. We greatly appreciate comments and suggestions of improvements by the journal reviewers, M. Krajewski and F. Pomoni-Papaioannou.

\section{REFERENCES}

Al-Helal, A.B., Whitaker, F.F., Xiao, Y., 2012. Reactive transport modelling of brine reflux: dolomitization, anhydrite precipitation, and porosity evolution. Journal of Sedimentary Research, $\mathbf{8 2}$ 196-215.

Allan, J.R., Wiggins, W.D., 1993. Dolomite reservoirs: geochemical techniques for evaluating origin and distribution. AAPG Continuing Education Course Note Series, $\mathbf{3 6}$.

Becker, F., 2002. Zechsteinkalk und Unterer Werra-Anhydrit (Zechstein 1) in Hessen: Fazies, Sequenzstratigraphie und Diagenese. Geologische Abhandlungen Hessen, 109.

Carmichael, S.K., Ferry, J.M., 2008. Formation of replacement dolomite in the Latemar carbonate buildup, Dolomites, northern Italy: Part 2. Origin of the dolomitizing fluid and the amount and duration of fluid flow. American Journal of Science, 308: 885-904.

Carmichael, S.K., Ferry, J.M., McDonough, W.F., 2008. Formation of replacement dolomite in the Latemar carbonate buildup, Dolomites, northern Italy: Part 1. Field relations, mineralogy, and geochemistry. American Journal of Science, 308: 851-884.

Chen, D., Qing, H., Yang, C., 2004. Multistage hydrothermal dolomites in the Middle Devonian (Givetian) carbonates from the Guilin area, South China. Sedimentology, 51: 1029-1051.

Chen, B., Joachimski, M.M., Shen, S., Lambert, L.L., Lai, X., Wang, X., Chen, J., Yuan, D., 2013. Permian ice volume and palaeoclimate history: oxygen isotope proxies revisited. Gondwana Research, 24: 77-89.
Clark, D.N., 1980. The diagenesis of Zechstein carbonate sediments. Contributions to Sedimentology, 9: 167-203.

Durakiewicz, T., 1996. Electron emission controller with pulsed heating of filament. International Journal of Mass Spectrometry, 156: $31-40$.

Dyjaczyński, K., Peryt, T.M., 2014. Controls on basal Zechstein (Wuchiapingian) evaporite deposition in SW Poland. Geological Quarterly, 58 (3): 465-482.

Dyjaczynski, K., Górski, M., Mamczur, S., Peryt, T.M., 2001 Reefs in the basinal facies of the Zechstein Limestone (Upper Permian) of Western Poland. Journal of Petroleum Geology, 24: 265-285.

El-Tabakh, M., Mory, A., Schreiber, B.C., Yasin, R., 2004. Anhydrite cements after dolomitization of shallow marine Silurian carbonates of the Gascoyne Platform, Southern Carnarvon Basin, Western Australia. Sedimentary Geology, 164: 75-87.

Friedman, I., O'Neil, J.R., 1977. Compilation of stable isotope fractionation factors of geochemical interest. USGS Professional Paper, 440-K: 1-12

Füchtbauer, H., 1980. Composition and diagenesis of a stromatolitic bryozoan bioherm in the Zechstein 1 (northwestern Germany). Contributions to Sedimentology, 9: 233-251.

Gao, G., Land, L.S., 1991. Early Ordovician Cook Creek Dolomite, Middle Arbuckle Group, Slick Hills, SW Oklahoma, USA: origin and modification. Journal of Sedimentary Petrology, 61: 161-173. 
Garcia-Fresca, B., Lucia, F.J., Sharp, J.M., Jr., Kerans, C., 2012. Outcrop-constrained hydrogeological simulations of brine reflux and early dolomitization of the Permian San Andres Formation. AAPG Bulletin, 96: 1757-1781.

Gregg, J.M., Shelton, K.L., Johnson, A.W., Somerville, I.S., Wright, W.R., 2001. Dolomitization of the Waulsortian Limestone (Lower Carboniferous) in the Irish Midlands. Sedimentology, 48: 745-766.

Habermann, D., Neuser, R.D., Richter, D.K., 1996. Hochauflösende Spektralanalyse der Kathodolumineszenz (KL) von Dolomit und Calcit: Beispiele der Mn- and SEE-aktivierten KL in Karbonatsedimente. Zentralblatt für Geologie und Paläontologie, (I): 145-157.

Hardie, L.A., 1987. Dolomitization: a critical view of some current views. Journal of Sedimentary Petrology, 57: 166-183.

Hryniv, S., Peryt, T.M., 2010. Strontium distribution and celestite occurrence in Zechstein (Upper Permian) anhydrites of West Poland. Chemie der Erde, 70: 137-147.

Jasionowski, M., 2010. Diagenesis of the Zechstein Limestone (Ca1) carbonates on the Wolsztyn High (south-west Poland). In: Petroleum Geological Atlas of the Southern Permian Basin Area (eds. J.C. Doornenbal and A.G. Stevenson): 146-147. EAGE Publications, b.v. (Houten).

Jasionowski, M., Durakiewicz, T., Peryt, T.M., 2000. Rafy wapienia cechsztyńskiego (Ca1) na wyniesieniu wolsztyńskim w świetle badań stabilnych izotopów tlenu i węgla (in Polish). Przegląd Geologiczny, 48: 468.

Jones, B., 2005. Dolomite crystal architecture: genetic implications fort he origin of the Tertiary dolostones of the Cayman Islands. Journal of Sedimentary Research, 75: 177-189.

Kaczmarek, S., Sibley, D.F., 2011. On the evolution of dolomite stoichiometry and cation order during high-temperature synthesis experiments: An alternative model for the geochemical evolution of natural dolomites. Sedimentary Geology, 240: 30-40.

Karnkowski, P.H., 1999. Origin and evolution of the Polish Rotliegend Basin. Polish Geological Institute Special Papers, 3.

Kiersnowski, H., Paul, J., Peryt, T.M., Smith, D.B., 1995. Facies, paleogeography, and sedimentary history of the Southern Permian Basin in Europe. In: The Permian of Northern Pangea (eds. P.A. Scholle, T.M. Peryt and D.S. Ulmer-Scholle), 2: 119-136. Springer, Berlin.

Kiersnowski, H., Peryt, T.M., Buniak, A., Mikołajewski, Z., 2010. From the intra-desert ridges to the marine carbonate island chain: middle to late Permian (Upper Rotliegend-Lower Zechstein) of the Wolsztyn-Pogorzela high, west Poland. Geological Journal, 44: 319-335.

Kijewski, P., 1981. Dolomitization of Ca1 carbonate rocks in copper mine area (in Polish with English summary). Przegląd Geologiczny, 29: 501-507.

Kotarba, M.J., Peryt, T.M., Kosakowski, P., Więcław, D., 2006. Organic geochemistry, depositional history and hydrocarbon generation modelling of the Upper Permian Kupferschiefer and Zechstein Limestone strata in south-west Poland. Marine and Petroleum Geology, 23: 371-386.

Krzywiec, P., Gutowski, J., Walaszczyk, I., Wróbel, G., Wybraniec, S., 2009. Tectonostratigraphic model of the Late Cretaceous inversion along the Nowe Miasto-Zawichost Fault Zone, SE Mid-Polish Trough. Geological Quarterly, 53 (1): 27-48.

Land, L.S., 1985. The origin of massive dolomite. Journal of Geological Education, 33: 112-125.

Lorenc, S., 1975. Petrography and facies differentiation in the Werra limestones and anhydrite rocks, Fore-Sudetic Monocline, SW Poland (in Polish with English summary). Geologia Sudetica, 10: 59-104.

Lumsden, D.N., 1979. Discrepancy between thin section and X-ray estimates of dolomite in limestone. Journal of Sedimentary Petrology, 49: 429-436.
Lumsden, D.N., Chimahusky, J.S., 1980. Relationship between dolomite nonstoichiometry and carbonate facies parameters. SEPM Special Publication, 28: 123-137.

Machel, H., 2004. Concepts and models of dolomitization: a critical reappraisal. Geological Society Special Publications, 235: 7-63.

Machel, H.G., Burton, E.A., 1991. Factors governing the cathodoluminescence in calcite and dolomite, and their implications for studies of carbonate diagenesis. SEPM Short Course, 25: 37-57.

Magaritz, M., Peryt, T.M., 1994. Mixed evaporative and meteoric water dolomitization; isotope study of the Zechstein Limestone (Upper Permian), southwestern Poland. Sedimentary Geology, 92: 257-272.

McCrea, J.M., 1950. On the isotopic geochemistry of carbonates and a paleotemperature scale. Journal of Chemical Physics, 18: 849-857.

McKenzie, J.A., 1981. Holocene dolomitization of calcium carbonate sediments from the coastal sabkhas of Abu Dhabi, U.A.E.: A stable isotope study. Journal of Geology, 89: 185-198.

Melim, L.A., Swart, P.K., Eberli, G.P., 2004. Mixing-zone diagenesis in the subsurface of Florida and the Bahamas. Journal of Sedimentary Research, 74: 904-913.

Michalik, M., 2001. Diagenesis of the Weissliegend sandstones in the south-western margin of the Polish Rotliegend Basin. Prace Mineralogiczne, 91: 3-171.

Nader, F.H., Swennen, R., Ellam, R., 2004. Reflux stratabound dolostone and hydrothermal volcanism-associated dolostone: a two-stage dolomitization model (Jurassic, Lebanon). Sedimentology, 51: 339-360.

Peryt, D., Peryt, T.M., Raczyński, P., Chłódek, K., 2012. Foraminiferal colonization related to the Zechstein (Lopingian) transgression in the western part of the Wolsztyn Palaeo-Ridge area, Western Poland. Geological Quarterly, 56 (3): 529-546.

Peryt, T.M., 1984. Sedimentation and early diagenesis of the Zechstein Limestone in Western Poland (in Polish with English summary). Prace Instytutu Geologicznego, 109: 1-70.

Peryt, T.M., 1987. The Zechstein (Upper Permian) Main Dolomite deposits of the Leba elevation, northern Poland. Diagenesis. Lecture Notes in Earth Sciences, 10: 225-252.

Peryt, T.M., Magaritz, M., 1990. Genesis of evaporite-associated platform dolomite: case study of the Main Dolomite (Zechstein, Upper Permian), Leba elevation, northern Poland. Sedimentology, 37: 745-761.

Peryt, T.M., Peryt, D., 2012. Foraminiferal and geochemical records of environmental changes during Zechstein Limestone (Lopingian) deposition in Northern Poland. Geological Quarterly, $\mathbf{5 6}$ (1): 187-198.

Peryt, T.M., Scholle, P.A., 1996. Regional setting and role of meteoric water in dolomite formation and diagenesis in an evaporite basin: studies in the Zechstein (Permian) deposits of Poland. Sedimentology, 43: 1005-1023.

Peryt, T.M., Geluk, M.C., Mathiesen, A., Paul, J., Smith, K., 2010a. Zechstein. In: Petroleum Geological Atlas of the Southern Permian Basin Area (eds. J.C. Doornenbal and A.G. Stevenson): 123-147. EAGE Publications, b.v. (Houten).

Peryt, T.M., Hałas, S., Hryniv, S.P., 2010b. Sulfur and oxygen isotope signatures of Late Permian Zechstein anhydrites, West Poland: seawater evolution and diagenetic constraints. Geological Quarterly, 54 (4): 387-400.

Peryt, T.M., Durakiewicz, T., Kotarba, M.J., Oszczepalski, S., Peryt, D., 2012a. Carbon isotope stratigraphy of the basal Zechstein (Lopingian) strata in Northern Poland. Geological Quarterly, 56 (2): 285-298.

Peryt, T.M., Raczyński, P., Peryt, D., Chłódek, K., 2012b. Upper Permian reef complex in the basinal facies of the Zechstein Limestone (Ca1), western Poland. Geological Journal, 47: 537-552.

Peryt, T.M., Hałas, S., Peryt, D., 2014. Carbon and oxygen isotopic composition and foraminifera of condensed basal Zechstein 
(Upper Permian) strata in western Poland: environmental and stratigraphic implications. Geological Journal, DOI: 10.1002/gj.2549

Raczyński, P., 2000. Zespoły organizmów w kompleksie rafowym wapienia cechsztyńskiego (Ca1) na wyniesieniu wolsztyńskim (in Polish). Przegląd Geologiczny, 48: 469-470.

Radke, B.M., Mathias, R.L., 1980. On the formation and occurrence of saddle dolomite. Journal of Sedimentary Petrology, 50: 1149-1168.

Rahimpour-Bonab, M., Esrafili-Dizaji, B., Tavakoli, V., 2010. Dolomitization and anhydrite precipitation in Permo-Triassic carbonates at the South Pars gasfield, offshore Iran: Controls on reservoir quality. Journal of Petroleum Geology, 33: 43-66.

Resak, M., Narkiewicz, M., Littke, R., 2007. New basin modelling results from the Polish part of the Central European Basin system: implications for the Late Cretaceous-Early Paleogene structural inversion. International Journal of Earth Sciences, $\mathbf{9 7}$ 955-972.

Schobben, M., Joachimski, M.M., Korn, D., Leda, L., Korte, C., 2014. Palaeotethys seawater temperature rise and an intensified hydrological cycle following the end-Permian mass extinction. Gondwana Research, 26: 675-683.

Scholle, P.A., 1995. Carbon and sulphur isotope stratigraphy of the Permian and adjacent intervals. In: The Permian of Northern Pangea (eds. P.A. Scholle, T.M. Peryt and D.S. Ulmer-Scholle), 1: 133-149. Springer, Berlin.
Sibley, D.F., Gregg, J.M., 1987. Classification of dolomite rock textures. Journal of Sedimentary Petrology, 57: 967-975.

Smith, D.B., 1980. The evolution of the English Zechstein basin. Contributions to Sedimentology, 9: 7-34.

Sylwestrzak, J., 2000. Zróżnicowanie raf mszywiołowych Ca1 w świetle wyników badań petrograficznych i izotopowych (streszczenie posteru) (in Polish). Przegląd Geologiczny, 48: 465.

Tucker, M.E., Hollingworth, N.T.J., 1986. The Upper Permian Reef Complex (EZ1) of North East England: diagenesis in a marine to evaporitic setting. In: Reef Diagenesis (eds. J.H. Schroeder and B.H. Purser): 270-290. Springer, Berlin.

Vasconcelos, C., McKenzie, J.A., Warthmann, R., Bernasconi, S.M., 2005. Calibration of the $\delta^{18} \mathrm{O}$ paleothermometer for dolomite precipitated in microbial cultures and natural environments. Geology, 33: 317-320.

Warren, J., 2000. Dolomite: occurrence, evolution and economically important associations. Earth-Science Reviews, 52: 1-81.

Wilson, E.N., Hardie, L.A., Phillips, O.M., 1990. Dolomitization front geochemistry, fluid flow patterns, and the origin of massive dolomite: the Triassic Latemar buildup, northern Italy. American Journal of Science, 290: 741-796.

Wright, W.R., Somerville, I.D., Gregg, J.M., Shelton, K.L., Johnson, A.W., 2004. Irish Lower Carboniferous replacement dolomite: isotopic modeling evidence for a diagenetic origin involving low-temperature modified seawater. Geological Society Special Publications, 235: 75-97. 